\title{
Deterministic and Contingent Factors in the Genesis of Agribusiness Clusters: The Pigmeat Industry in Nineteenth-Century Catalonia
}

\author{
Pere Castell ${ }^{1, *(D)}$ and Ramon Ramon-Muñoz ${ }^{2}$ (D)
}

Citation: Castell, P.; Ramon-Muñoz, R. Deterministic and Contingent Factors in the Genesis of Agribusiness Clusters: The Pigmeat Industry in Nineteenth-Century Catalonia. Land 2022, 11, 385. https://doi.org/ 10.3390/land11030385

Academic Editors: Francisco

Manuel Parejo-Moruno, Antonio Miguel Linares Luján, José Francisco Rangel Preciado and Esteban Cruz Hidalgo

Received: 31 December 2021

Accepted: 3 March 2022

Published: 5 March 2022

Publisher's Note: MDPI stays neutral with regard to jurisdictional claims in published maps and institutional affiliations.

Copyright: (c) 2022 by the authors. Licensee MDPI, Basel, Switzerland. This article is an open access article distributed under the terms and conditions of the Creative Commons Attribution (CC BY) license (https:// creativecommons.org/licenses/by/ $4.0 /)$.
1 Elisava, Facultat de Disseny i Enginyeria de la Universitat de Vic-Universitat Central de Catalunya (UVic-UCC), La Rambla 30-32, 08002 Barcelona, Spain

2 Department of Economic History, Institutions, Politics and World Economy, Faculty of Economics and Business, University of Barcelona, Diagonal 690, 08034 Barcelona, Spain; ramon@ub.edu

* Correspondence: pcastell@elisava.net

\begin{abstract}
This paper deals with the location, origins, and early development of clusters and industrial districts in the agribusiness sector. It considers the case of the meat processing industry in the second half of the 19th century in Catalonia, a prosperous southern-European region in the period when this industry emerged. By constructing an index of potential locations at the municipal level, the paper discusses whether, and to what extent, deterministic factors explain the genesis of pigmeat processing clusters. The paper concludes that although these latter factors need primary consideration, contingency, particularly human agency, may also play a non-negligible role. As an illustration, this study pays particular attention to the cluster of Vic, which developed around this middle-sized town in central Catalonia. It became a leading meat cluster in early 20th-century Spain, even though it was not better suited to this industry than other Catalan localities where meat companies had also emerged.
\end{abstract}

Keywords: cluster; industrial district; meat industry; life cycle; window of locational opportunity; human agency

\section{Introduction}

The historical analysis of clusters and industrial districts has attracted remarkable attention in the last two decades (e.g., see the chapters in [1-3]). Starting from pioneering and some more recent works in the field (e.g., [4-11]), the historical literature has made it possible to improve the understanding of the factors and contexts that originated the emergence of spatial agglomerations of firms and the different paths which they followed.

However, despite its growing interest, there are still areas that merit further research. The agribusiness clusters are one of these areas. In 2016, M. Molema, Y. Segers, and E. Karel pointed out, "the literature on the geographical dimension of agribusiness is still scarce and is mainly written from a national perspective" ([12] p. 10). Clusters in rural areas have been considered conducive to rural development (e.g., [13-15]), and this is an important reason for turning our attention to analysing the historical roots and long-term performance of agribusiness clusters.

The evolution of clusters and industrial districts is another area that deserves further attention. This is indeed a controversial issue. Clusters tend to evolve similarly to a life cycle, although they do not follow a deterministic pattern. They may decline after a period of growth, but they can also start a process of renewal, adaptation, and transformation that may lead to a re-emergence ([16,17], see also, e.g., [18-21]). Moreover, the analysis of the early stages of the life cycle of clusters is particularly complex: it is extremely difficult to analyse something that does not yet fully exist, in this case a cluster which is not fully formed, or which may not eventually emerge. In other words, it does not seem very 
easy to establish the exact causes for a business concentration originating in a particular location [22]. One fruitful avenue for overcoming these difficulties is to place the origins and early development of clusters in the framework of the determinants of the spatial distribution of economic activity. This means considering that business agglomerations can be determined by a variety of factors, from deterministic to more contingent; however, it also means applying concepts from evolutionary economics, such as the Window of Locational Opportunity (hereafter WLO). This concept describes the initial location process of a new sector as probabilistic rather than deterministic $[23,24]$.

The present study aims to contribute to these latter issues. By exploring the case of the pigmeat industry in Catalonia in the second half of the 19th century, this paper examines the factors that might explain the location of pigmeat processing firms across the space and, later on, the emergence and early development of pigmeat processing clusters. After providing detailed quantitative evidence at the municipal level, the article poses an intriguing question: why did pigmeat firms sometimes locate in municipalities that a priori were not always the best suited for this activity to emerge? In answering this question, we pay particular attention to the industrial district of Vic, which developed around this middle-sized town in central Catalonia and became a leading pigmeat cluster in early 20th century Spain. Methodologically, this research combines qualitative evidence and quantitative analysis to construct an index of apparent suitability of locations.

This study is part of a broader research project on the pigmeat industry in 19th-and 20th-century Catalonia. Pigmeat industrial processing is representative of a relatively new industry that was deeply embedded in rural areas. In Catalonia, this manufacture emerged in the last quarter of the 19th century when meat processing underwent the transition from the putting-out system to the factory system. Although there were initially few firms devoted to processing pigmeat, its leading centres soon evolved towards agribusiness clusters. They were also characterised by a close interaction between animal husbandry in the countryside and manufacturing work carried out in towns and cities. Currently, the meat sector plays a relevant, although controversial, role in the economies of some European countries and regions. In Catalonia, where the agri-food sector is one of the main sectors of its economy, the largest part of agri-food exports consists of meat and processed meat products [25]. The remarkable role of the meat processing industry, which in Catalonia still operates in clusters integrating industry and rural husbandry, cannot be well-understood without considering the origins of the industry.

Aside from this introduction, the remainder of the present study is organised into five more sections. Section 2 reviews the theoretical framework of the life cycle of clusters and, in particular, the initial stages of their evolution. The third section looks at the origins and formation of the Vic district before the 1890s, and paves the way for the coming sections. Section 4 has a methodological nature. It is devoted to constructing an index of the potential locations of the pigmeat processing industry in late-19th century Catalonia. The fifth section discusses these results by considering the role of deterministic factors, contingency, and human agency in the spatial locations of the Catalan meat processing companies during the second half of the 19th century. Human agency is analysed using a micro-perspective for the case of Vic. Finally, Section 6 concludes by stressing that deterministic factors were essential, but human agency also played a non-negligible role in explaining the early development of clusters.

\section{The Genesis of Clusters: A Theoretical Approach}

Districts and clusters are dynamic economic realities. Why do they locate and emerge in a particular place? Unfortunately, there is no single answer to this question. The historical literature on the determinants of industrial location has examined whether and when location patterns are more connected to factor endowments, such as natural factors linked to raw materials that are essential for the industry (e.g., [4,26]), as suggested by the Hecksher-Ohlin theorem of international trade, or to market access and increasing returns to scale, as predicted by the New Economic Geography (e.g., [27-33]). However, 
the emergence of clusters can also be related to historical accidents [34]. Therefore, there is a vast range of factors for explaining cluster location and formation, from the most specific to the most indeterminate. Hence, with few exceptions, it is somewhat unpredictable to answer why and where a new economic agglomeration will occur.

The potential unpredictability of industrial location is neither new nor unknown. Randomness may influence the initial phase of clusters, a topic that connects with A. Scott, M. Storper, and R. Walker's pioneering contributions [23,35]. Adopting an evolutionary perspective, these authors analysed industrial geography and showed how processes of continuity and discontinuity had shaped it. Although the growth of districts shows that processes of spatial dependence reinforce the continuity of geographical locations, as suggested by the New Economic Geography, this dependence is not always present in the formative stage or genesis of a potential cluster. Discontinuities also arise in the earlier phases of clusters formation and a window of opportunity opens for industrial development to transmute location. Since the late 1980s and the 1990s, several authors have analysed and developed the concept of WL0 in-depth [23,24,36-39].

Thus, each disruption opens up the possibility to develop a new growth location detached from the spatial dependence of the existing ones. In a nutshell, this is the concept we know as the WLO. In addition, this concept captures the wide range of possible locations that emerge when the first companies of a nascent industry have to locate. Furthermore, the window of opportunity can also be more or less open, depending on the influence of deterministic locational factors in developing the new activity.

One of the factors that explains the degree of openness of the WLO is, of course, the stage of formation of a cluster. There is often a great deal of technological divergence among the few existing enterprises in the start-up phase of the industry. As a result, it is difficult to identify the factors necessary for optimal location. In general, a new company's needs are not specific but rather generic, such as well-trained human capital, access to essential services, and availability of primary capital resources. These factors are generally located randomly, in different places, though mainly in large cities, with generic urbanisation economies [40]. In this case, spin-offs are a recurrent mechanism for transferring knowledge. Economies of agglomeration or localisation also generate specific features. As a result of these processes, districts become consolidated and homogenised, developing the factors specific to their functioning [39]. Therefore, in its earlier and formative stages, the indeterminacy of the needs of the new cluster opens up the so-called location window in geographical terms or WLO. Conversely, this window closes as the districts develop.

Another aspect that helps open up the range of location possibilities is that new activities tend to work with wider gross margins in their early stages $[23,24]$. This flexible way of operating is because products are new and have higher prices due to their exclusivity or lack of supply. The viability of the new activity is, therefore, not challenged or in danger, even if the choice of location is not the best or has not proven to be the most efficient in terms of economic profitability. Moreover, the returns from these first initiatives leave room for the district to build up the necessary factors for its consolidation and development, such as human capital. Similarly, contingent factors may become fundamental in the cluster's early phases. One of these factors is human agency [17], understood as the actions and decisions of the agents, because it determines how the district will be shaped in the future.

In short, the initial location of a firm can be more probabilistic than deterministic $[24,36]$. Although the window of opportunity may a priori privilege some possible locations over others due to the existence of certain factors, it is possible that a cluster finally locates following more indeterminate patterns, developing itself outside geographical areas that seemed more likely to host and develop the cluster. It is precisely this probabilistic component that allows us to understand why locations change, why past-path processes of spatial dependence break down, and why previously established factor endowments end up being non-determinant.

How does the previous discussion apply to the location of agribusiness clusters? A significant part of the existing literature has associated discontinuity with technological 
change and disruptive innovations [38] that break with past dependencies [16]. However, this type of approximation neglects self-accumulative processes derived from interdependencies developed within the framework of input-output relationships, which characterise industrial agglomerations with inter-sectoral relationships, i.e., the interdependence between industry and agriculture [41]. Moreover, these inter-sectoral agglomerations, of which agro-industrial districts form a part, are generally characterised by a lower technological content than other industrial districts. Therefore, whereas discontinuities may also play a critical role in explaining the location and formation of agribusiness clusters, they might be less associated with disruptive technological change and, at the same time, with a more inter-sectoral content. For this last reason, agro-industrial clusters are expected to be located closer to raw materials [4,42]. Although their influence on location patterns cannot be ignored, this is not the only factor of location, as studies on food manufacturers have shown (e.g. [43]). In the end, contingency might also have a role to play in the location and origin of agribusiness clusters [23], placing them in line with clusters populated by firms with higher technological content, as suggested by the WLO concept.

\section{The Origins of the Pigmeat Processing Clusters in Catalonia: The Case of Vic}

What could, therefore, explain the origins and location in the territory of the pigmeat processing clusters? This section describes the formative stage of the Vic district and, by doing so, paves the way to analysing the initial location patterns of Catalonia's nascent pigmeat processing industry. As we will show, in the origins of the Vic cluster, we find a combination of supply and demand factors and endogenous and exogenous elements. On the supply side, factor endowments and natural resources facilitated access to pork meat and the availability of an underutilized labour supply. On the demand side, Barcelona acted as a dynamic market for processed meat products, which became more easily accessible after the railway connected Vic with the Catalan capital city. Moreover, the existence of commercial networks favoured access to external consumption markets.

The town of Vic and its district are located in north-eastern Catalonia; some $70 \mathrm{~km}$ north of Barcelona (see Figure 1). With about 14,500 inhabitants in the mid-19th century, Vic was, and still is, the capital and economic centre of a district and a county (Osona) that would eventually become one of the largest pig-derived sausage-industry agglomerations in the Iberian Peninsula.

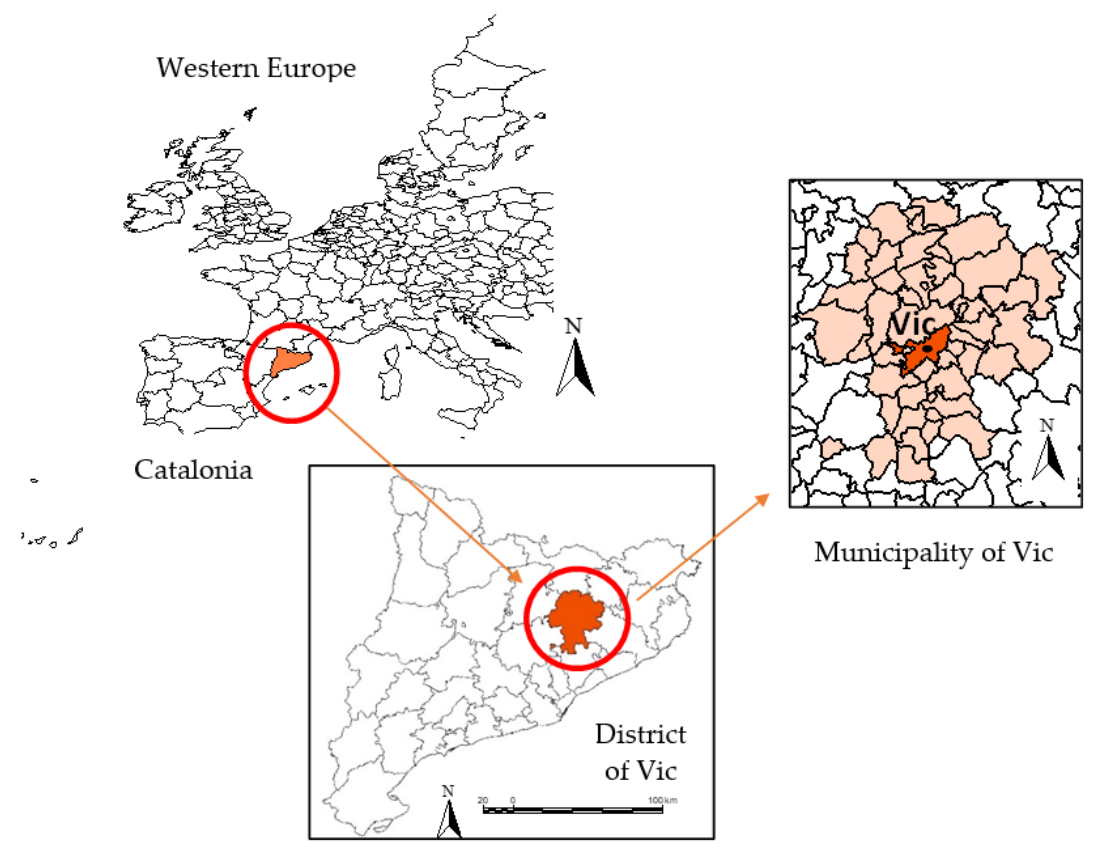

Figure 1. The location of Vic and its pigmeat processing district. Source: Authors' own elaboration based on [44-46]. 
Vic's specialisation in pork products did not come out of nowhere. First, it was founded on an industrial base in decline. With no significant coal deposits in Catalonia, the emerging cotton industry soon made extensive use of water energy, locating the factories near the banks of certain Catalan rivers, such as the Ter River (e.g., [47-49]. As Vic did not have hydraulic resources for motive power-the Ter River does not pass through the municipality of Vic, but rather a few kilometres to the north of the town-the town underwent an industrial crisis [50]. During the second half of the 19th century, the population declined from 14,343 inhabitants in 1857 to 12,105 in 1900 [51]. Furthermore, the textile crisis also resulted in an idle labour supply and probably underutilised commercial networks, which exerted a remarkable influence on the development of the meat processing district. For example, industrial pigmeat processing centres that emerged later on, such as Olot (the capital city of the north-eastern county of La Garrotxa) and Sant Llorenç de Morunys (in the county of Solsonès, in central Catalonia), also developed after undergoing a crisis in the local textile industry [52,53].

Interestingly, the production of sausages had a non-negligible tradition in Vic. Although the establishment of the first industrial meat companies dates back to the 1880s, when some large-scale projects were set up, the region's production tradition in meat processing goes further back. By the mid-19th century, we find evidence of a dynamic sausage business flourishing around the town of Vic [54]. This tradition is perhaps not surprising. In the 1860s, the district of Vic, namely the town and its hinterland, was not the leading area of pig production, but it did have a reasonably large percentage of pigs compared to other districts and counties in Catalonia [55].

Hawkers and traders based in Vic travelled around the district's farmhouses to sell their wares and buy agricultural products. Thus, meat products manufactured from pigs slaughtered at home, i.e., farmers' homemade sausages, were bought by local traders to be sold in Barcelona, a large city whose demand and consumption of meat and processed meat products rapidly increased during the second half of the 19th century [56,57]. Fortunately, we have evidence of this trade through the records of the movement of meat that traders declared on entering and leaving the town in the local consumer offices. This documentation is currently in the Arxiu Municipal de Vic (Municipal Archive of Vic, hereafter AMV). A detailed analysis of the information regarding Bernat Marquet, a merchant who operated in the town in 1857, shows that this local merchant bought about eight metric tonnes of sausage throughout the season. Notably, the slight difference between the weight of the bought and sold goods indicates the apparent existence of trade in manufactured (finished) sausages. According to the available information, Marquet bought these manufactured sausages in the rural areas of the Vic district and then sold them in Barcelona. In the town of Vic, Marquet was not the only merchant who carried out this type of business. From 1857 to 1864 , the number of merchants devoted to the same activity grew steadily. In 1864, there were already eight taxpayers of processed meat products and they sold almost 48 metric tonnes of sausage.

Traders played a central role in the organisation of the manufactured meat business. First, they provided the district farmers with a part of the inputs necessary to produce meat products, such as salt. Second, they obtained homemade sausage from these farmers. Third, they later sold the sausages outside the local and regional boundaries in the final market. Although the details of this business are not well-known as yet, it seems evident that this was a domestic activity that was very fragmented, structured through an externalised organisation. This allowed self-consumption to coexist with the sale of part of the manufactured products, and channelled a large part of the livestock production from the district of Vic to Catalonia's capital, namely Barcelona. This organisation and structure are close to what we know as a putting-out system or proto-industrial organisational structure (e.g., [58]).

However, the meat processing business began to change during the 1870 s. The rising volume of traded products increased transaction costs, which emerged because of the traders' lack of information about the production process [54]. The key was the curing 
process, and the sausages were bought while still fresh to centralise the drying process in the plants installed by the local merchants on the rooftops of the town. This practice took root and gradually led to the internalisation and centralisation of the whole process of producing sausages. A turning point in the organisational transformation of this activity accelerated with the arrival of the railway in the district in 1870 and its capital, Vic, five years later.

The railway not only accelerated an organisational change in the production of processed meat products, but also had another consequence: it increased competition for local agriculture. The growing presence of foreign cereals forced a change in the county's agricultural specialisation, which meant a pronounced orientation towards livestock farming and increased the cultivation of potatoes and cereals for livestock [59-61]. These changes must be placed in the general context of the late-19th century agrarian crisis (e.g., [62-65], a consequence of the 19th century globalisation (e.g., [66]. Likewise, the arrival of the railway offered the possibility of importing other inputs, which, in this case, could help complement local production for the emerging meat processing industry, such as the abovementioned cereals, fodder, or even meat. In this connection, we estimate that $6 \%$ of the meat used in Vic arrived by train, in carrier boxes, at night and without refrigeration, from bordering districts [54].

At the same time as the arrival of the railway, the first records of 'dead meat' entering the town appeared [25]. This is not a simple coincidence, but evidence that a substitution process was taking place: the meat entered the town as raw material, in an unprocessed form, whereas prior to the 1870s, it had consisted mainly of sausages. Together with other anecdotal information, we take this finding as proof that the manufacturing process was developing inside the town of Vic, in some cases entirely, and confirmation that the town was undergoing a classical transition from the putting-out system to the factory system. Thus, unprocessed 'dead meat', leftover from home slaughtering and the home production of sausages in the rural hinterland, began to enter the town of Vic. Furthermore, climatic conditions facilitated bringing non-manufactured meat into the town: the district of Vic was characterised by cold winters, which was the season when most meat processing was carried out in the emerging meat processing factories in the town.

Prosperous as it became, Vic was not the only town in Catalonia where meat-processing firms sprang up in the second half of the 19th century. In 1896, and according to the available sources, this new industry had companies in nine different Catalan municipalities: Barcelona, Vic, Castellterçol, l'Aleixar, Figueres, Sant Feliu de Pallerols, Sant Pere de Torelló, Centelles, and Sant Just Desvern (see Figure 2). These villages, towns, and cities had, in total, 20 meat processing firms, of which the first two municipalities mentioned above accounted for more than half of these establishments, with six and five companies, respectively. Castellterçol and l'Aleixar had two firms each, and, finally, the rest of the municipalities mentioned had only one firm.

In this study, we use the data on pigmeat processing firms obtained from the Anuario Riera [67], a yearbook providing information on the location of firms by municipalities, complemented with records from the AMV on the firms that entered meat into the town of Vic. We considered those manufacturing companies that were classified as producers of sausages or meat derivatives; therefore we excluded those firms that seemed to only have a commercial purpose. In addition, we noted that the same company could be present in several municipalities. For these cases, we tried to determine the exact productive location, and eliminated references to the same company from our dataset because we assumed that they were commercial subsidiaries. This correction led to a substantial reduction in the number of meat companies, especially in the case of the city of Barcelona. Finally, in constructing our dataset, we realised that some locations, notably Vic and Barcelona, did not correspond to the actual place of the factory. Therefore, we made the corresponding corrections using the information from the AMV quoted above. 


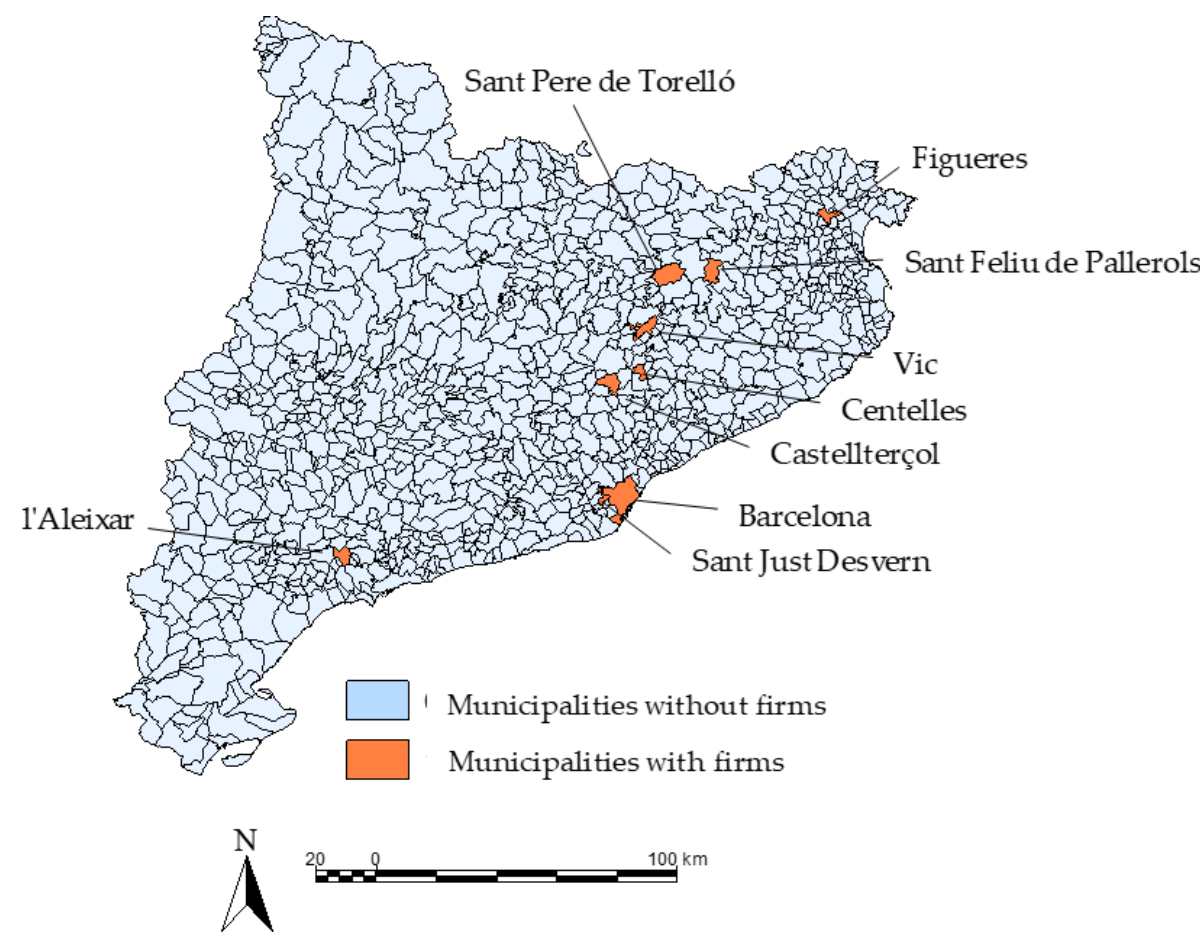

Figure 2. Location of meat-processing companies in Catalonia, 1896. Notes and sources: See Figure 1 and text.

Although we believe that our database of pigmeat-processing firms is robust, it is certain that by the 1890s, the meat-processing industry had very few manufacturing companies, particularly if we compare it with other agro-industrial activities. Accordingly, the industry was only located in a very small number of municipalities, 9 out of the 947 current Catalan municipalities. However, there is an explanation for such low numbers. At the end of the 19th century, this was still a nascent industry, an activity that had had a domestic nature until then. Moreover, particularly in rural areas, the homemade manufacture of processed meat products would persist until the second half of the 20th century. In any event, the reality that we can document consists of a new industry that initially emerged in nine different municipalities, although one of them, Vic, managed to stand out.

A first and tentative approach to this issue suggests that the pigmeat-processing industry was located and prospered in Vic because it was better endowed than other municipalities. Supply side factors might have favoured this municipality, but other factors from the demand-side could also have explained the location and emergence of the Vic industrial district. In the end, deterministic factors might explain the origins, emergence, consolidation and, finally, leadership of the Vic cluster. However, the reality is more complex, and the following sections provide evidence in this direction.

\section{The Construction of an Index on the Location Dynamics of the Catalan Meat Processing Industry: Sources, Data, and Methodology}

This section explains the construction of a new index at the municipal level to assess the influence of deterministic factors on the location of meat processing firms in Catalonia. Whereas some studies have analysed the determinants of industrial location in Catalonia by municipalities for recent years (e.g., [68]), the same cannot be said for the late 19th century. As explained above, the WLO concept argues that the initial locational process of a new sector is determined by probabilistic rather than deterministic factors $[24,36]$. The more influential the deterministic factors are in the location processes of economic activity, the more closed the window of possibilities for this location will be. Therefore, the greater the incidence of path dependence in the evolution of each location, the lesser the importance of other less predictable aspects. We followed a relatively simple strategy to establish 
the importance of deterministic factors relative to those that could be more contingent or discretionary. As a preliminary step, we identified factors which a priori should have the most significant influence on the initial location of the meat processing activity. The case of Vic, which we described above, allows us to determine these factors for the second half of the 19th century. The first is the availability of livestock, and, therefore, of meat. In addition, we also consider the existence of an environmental context that facilitated its preservation. The other factors that were present at the beginning of the Vic meat cluster are related to the growing demand for sausages in Barcelona, a relative abundance of unemployed labour because of the town's industrial decline and, finally, the availability of pre-existing commercial networks, which had arisen around the textile industry, and connected the county with the outside world.

Based on the previous description of the Vic cluster, we elaborated several variables that could capture the location factors of the Catalan meat processing industry. We constructed these variables at the current municipal level with data available for the second half of the 19th century. They are shown in the figure that includes Figure 3a-h.

The first of these (Figure 3a) shows the number of pigs per square Kilometre at the municipality level. More precisely, it shows the municipal density of pigs, which we estimated by considering the surface area of each district (roughly a county) and the 1865 census of pigs. To obtain the data on the pig density at the municipal level, we assigned to each municipality the average density of the district to which the considered locality belongs. The pig density variable attempts to approximate the availability of meat in the area in which each of the current Catalan municipalities is located. In addition, and complementing information on the pig density per area, Figure $3 \mathrm{~b}$ provides information on the pig density per 1000 inhabitants. We took the data on the number of pigs per district from E. Giralt [49], while we estimated pig densities by using data on the municipal area and municipal population from the Statistical Institute of Catalonia (hereafter Idescat) [51,69]. 


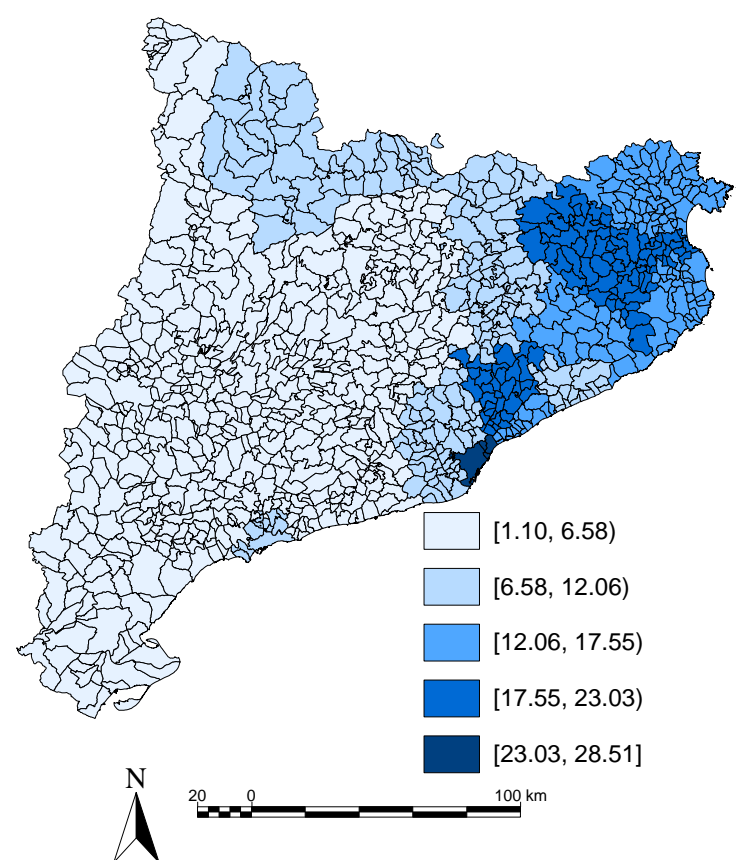

(a)

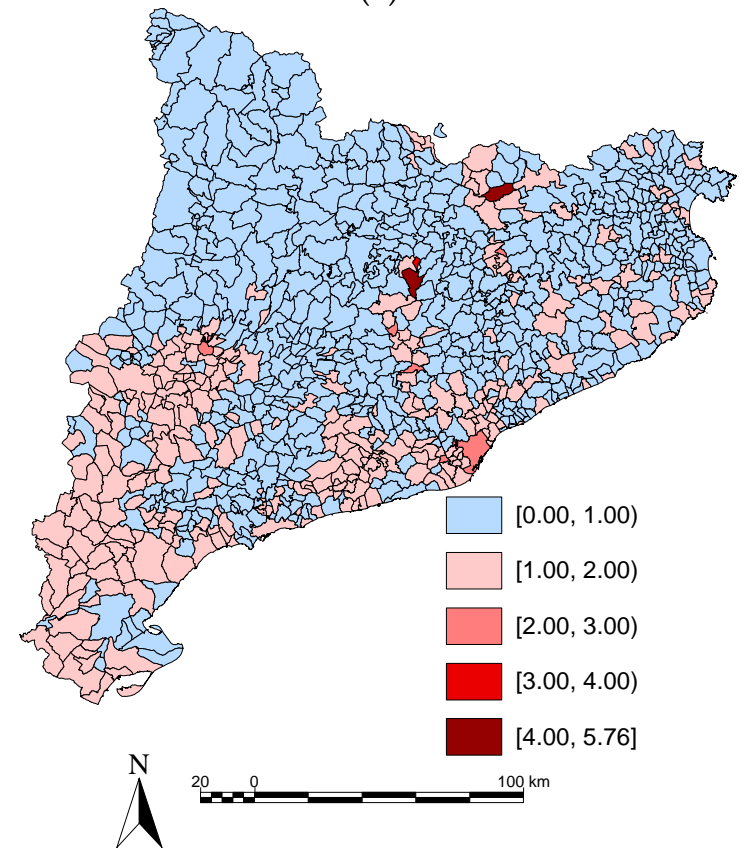

(c)

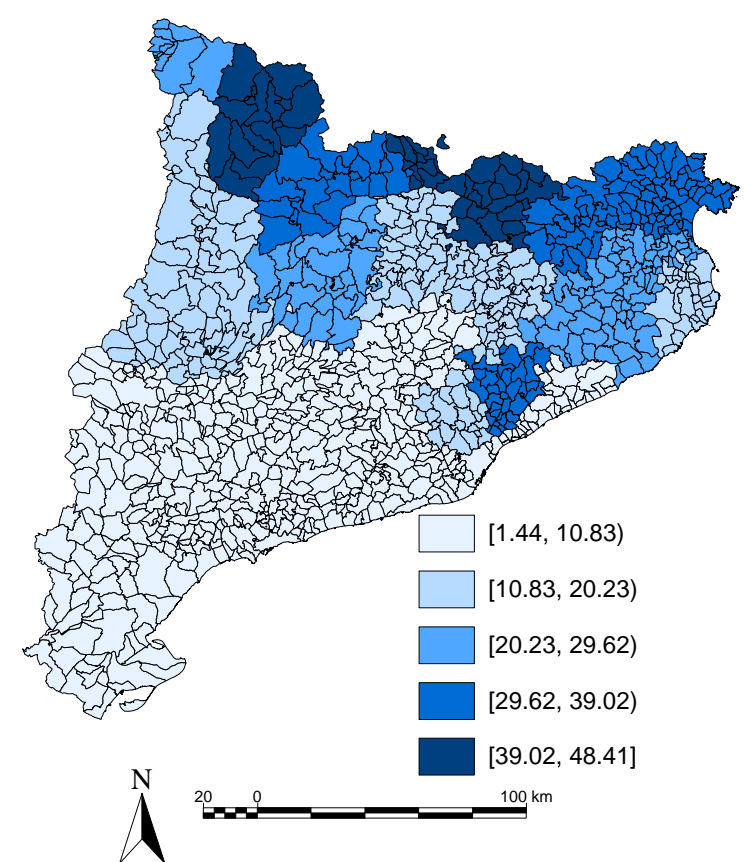

(b)

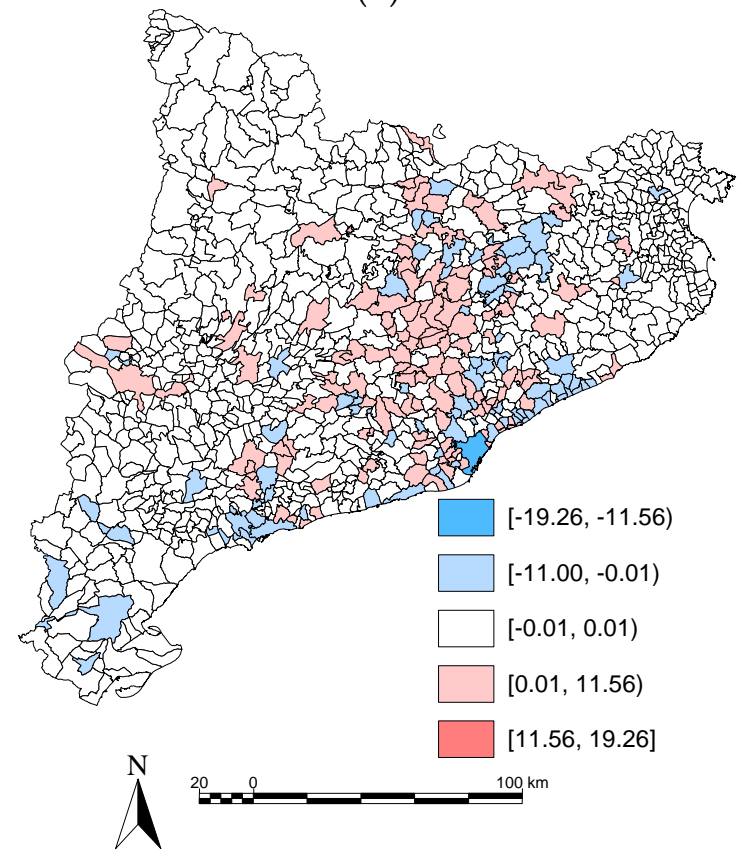

(d)

Figure 3. Cont. 


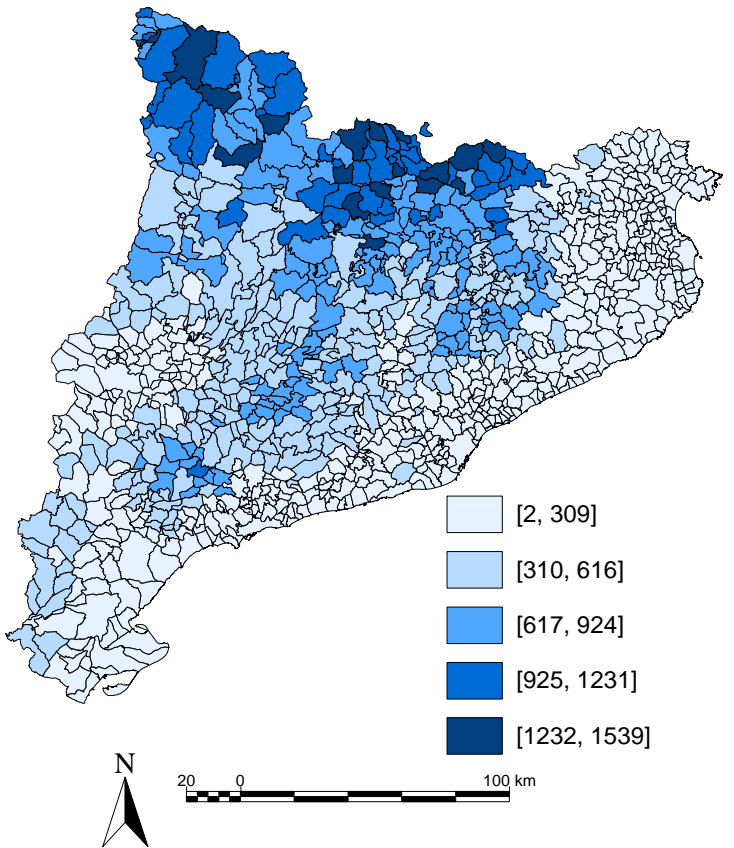

(e)

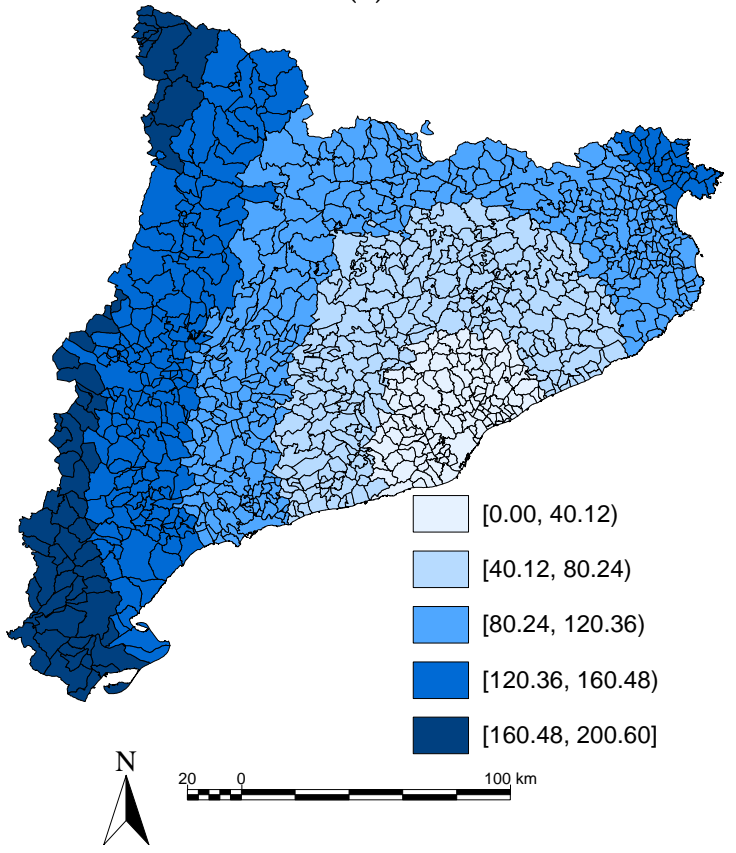

(g)

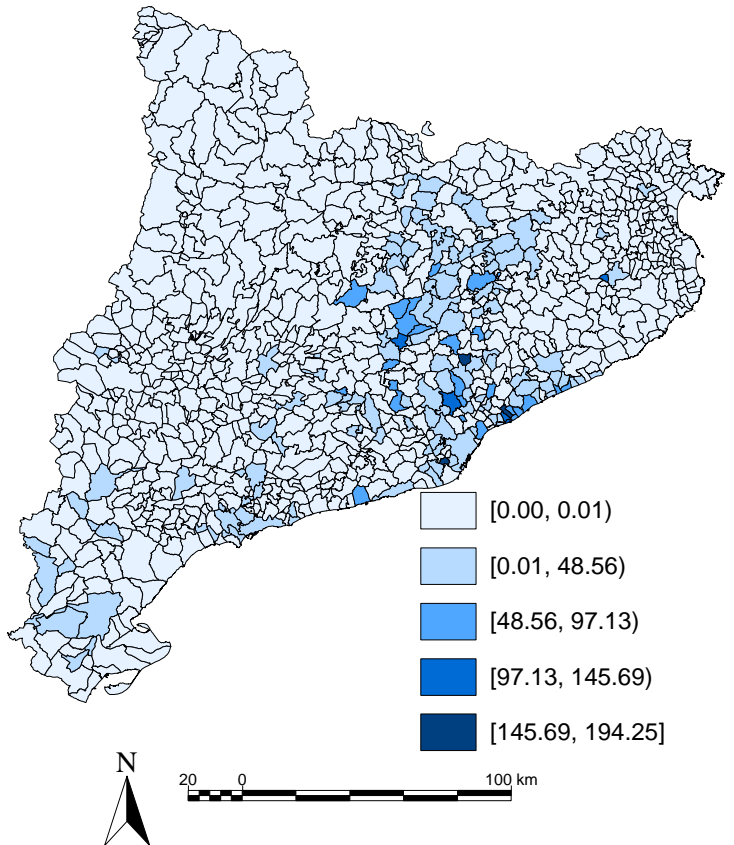

(f)

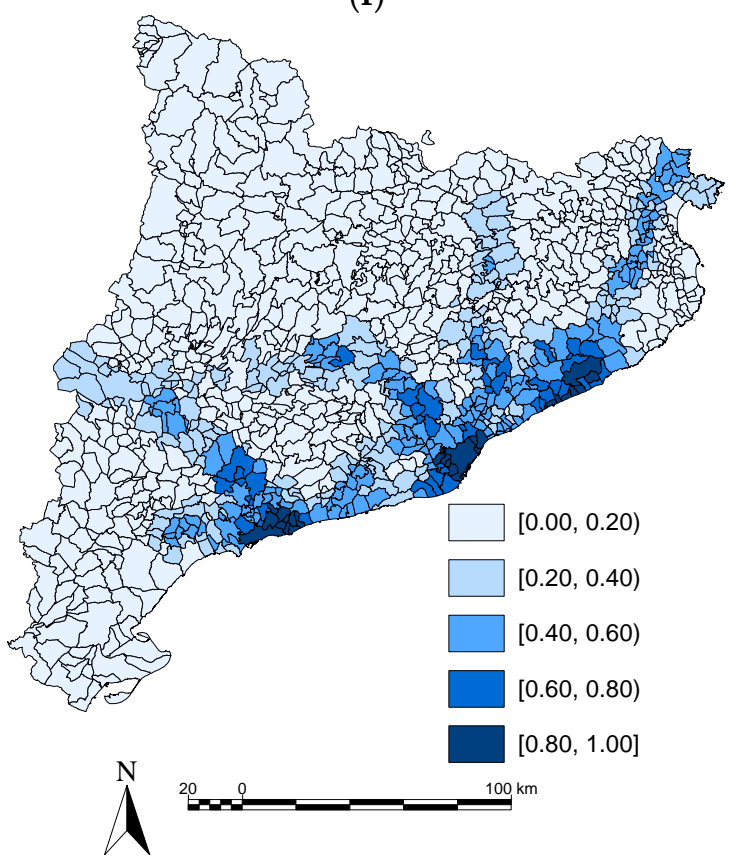

(h)

Figure 3. The main potential location factors in the Catalan pigmeat-processing industry in the second half of the 19th century by municipalities. Notes and sources: Authors' own elaboration based on [46] for geographical information, [55] for data on livestock, [49,51,55,69-72] for the data used to estimate livestock densities, population, and, finally, georeferenced location, which refers to the distance between all the current Catalan municipalities and Barcelona. There is no information on the number of wool looms in the province of Lleida in 1861, where this activity was probably very limited $[49,71]$. See also text and Figure 1. (a) Pig density per area. Unit: Number of heads $/ \mathrm{Km}^{2}$. (b) Pig density per population. Unit: Number of heads in 1865/1000 inhabitants in 1861. (c) Demographic trends. Unit: Population ratio 1900/1857. (d) Textile industry trends. Unit: Cotton loom proportion difference 1861/1931. (e) Altitude. Unit: Metres. (f) Textile industry activity. Unit: No. of cotton and wool Looms/1000 inhabitants in 1861. (g) Distance from Barcelona. Unit: Kilometres. (h) Railway accessibility. Unit: Distance gradient to closest train stations before 1891. 
The information presented in Figure $3 c, d$ attempts to measure the relative abundance of unemployed labour due to the local industrial decline. This probably cheaper and underutilised labour appears to have influenced the emergence of the meat-processing industry. We tested for two alternative variables. Figure $3 \mathrm{c}$ shows the relationship between the population of each municipality in 1900 (numerator) and 1857 (denominator) to determine the profile of those municipalities that were less dynamic in the period analysed. Population data were taken from Idescat [51]. According to what we have said above, we assume that if labour abundance can influence the origin and consolidation of meat-processing clusters, the demographic evolution will somehow help to capture labour supply trends. However, the $1900 / 1857$ population ratio correlates with the variable altitude (Coef. $-0.301, p=0.001$ ). This high correlation is explained by the depopulation of the mountain areas, which mainly determined territorial population trends. The population living in rural mountain areas migrated to the more dynamic urban centres, and this formed the basis of the urbanization process that was taking place in Catalonia in the second half of the 19th century [73-75].

Figure 3d presents new evidence to overcome the shortcomings of using the 1900/1857 population ratio to proxy for labour abundance. In particular, the variable presented in Figure $3 \mathrm{~d}$ aims to capture industrial decline in towns and cities, which ceteris paribus caused unemployment to increase. Due to the lack of more comprehensive information, and as the textile and, more specifically, the cotton industry achieved a preeminent position in Catalonia by the mid-19th century $[47,49,76,77]$, we take the number of cotton looms as a proxy for trends in the textile industry. We used information from J. Nadal and J.M. Benaul [49], who provide data on the total number of cotton looms in Catalonia. We computed the difference between the proportion of cotton machinery in each municipality in 1931 and 1861. We excluded the spinning branch of the cotton textile industry in our estimates [47]. Nevertheless, and according to the available data [49], the correlation between the evolution and location of weaving, on one hand, and spinning, on the other, is very high, namely $0.88(p$-value $=0.01)$. Similarly, we are well aware that cotton was not the only textile industry in the second half of the 19th century, though it was by far the main textile branch of textile evolution, accounting for around $75 \%$ of both the labour force and production value of the textile industry in mid-19th century Catalonia [71].

Figure 3e provides municipal data on altitude above sea level in metres. In the absence of complete data for the second half of the 19th century, we consider altitude as an approximation of the average temperature of the municipality. Although some areas have thermal inversion phenomena in Catalonia, the altitude approximates the average temperature quite well. Using information from the 42 local stations that validate the county climatological data published by Idescat [78], the Pearson correlation established between the annual average-temperature in 2018 and the altitude of each of the municipalities where these stations are located is very high $(-0.92)$, and, as expected, it is also negative. Therefore, we consider that the altitude variable proxies each locality's temperature relatively accurately. In addition, the altitude variable captures the natural conditions for meat preservation, albeit imperfectly.

Another factor that needs to be considered is the pre-existence of commercial networks that sustain the connection between supply and demand. This factor could have fostered the formation and consolidation of the meat clusters, as argued for the particular case of Vic. It is not easy to proxy for this factor. It could be hypothesised that commercial networks linking the town, its hinterland, and the rest of the country became stronger when the local textile industry progressed. Therefore, we assume that the strength of pre-existing commercial networks in a municipality might be, at least in part, associated with the textile industry's presence and size in that municipality, the leading industrial sector in 19th century Catalonia, as argued above. We use the number of cotton and wool looms in 1861 at the municipal level as a proxy for capturing the presence and size of the local textile industry. Although cotton and wool were not the only textile industries in Catalonia, we point out again that they accounted for the bulk of the textile industry [71]. To estimate the relative weight of these two textile branches by municipalities, we have calculated the total 
number of cotton and wool looms relative to the population, as presented in Figure 3f. We obtained these data from $[49,51]$.

The information presented in Figure $3 \mathrm{~g}$ shows the distance, in kilometres, between every Catalan municipality and Barcelona, a leading and very dynamic consuming centre in the second half of the 19th century, as argued in the previous section. Barcelona was also a dynamic trading centre, and, therefore, the distance to Barcelona may also capture access to foreign markets. Distance was calculated by considering the geo-referenced positioning of each municipality's largest population centre and the city of Barcelona. The primary objective of this variable is to capture the impact of demand on the origins and early development of a potential municipal cluster, assuming that the closer the municipality was to Barcelona, the more intense the impact of demand.

The data presented in Figure $3 \mathrm{~g}$ are complemented with information on railways shown in Figure 3h. Railways had a clear impact on market access, and as argued above, this was also true for the case of Vic and other areas in Europe and the United States where the meat processing industry emerged and prospered (e.g., [79-83]). To measure the potential impact of railways on cluster genesis, we have constructed an index that considers the distance between each municipality and its closest train station(s). We started with the dataset used in R. Ramon-Muñoz and J.M. Ramon-Muñoz [72], who provide evidence on the Catalan municipalities with railway stations before 1891 through a dichotomous variable. Using this information, we developed a new and semi-continuous variable that also considers the distance from any locality with a railway station up to a maximum geometric radius of $25 \mathrm{~km}$. For example, a locality with a train station and no other railroad stations in a radius of $25 \mathrm{~km}$ has an index of 1, whereas a locality more than $25 \mathrm{~km}$ away from a railway station has an index of 0 . The index varies depending on the proximity of the considered municipality to its (their) closest railway station(s). The distance of $25 \mathrm{~km}$ corresponds to the average dispersion of the county's municipalities relative to the county's capital town. In Catalonia, the capital towns of the counties centralised a large part of the purchases made by the county's population. The distance we use has also been used in other studies (e.g., [84]) and has also been considered an appropriate distance to access services of a regional-local nature [85].

More formally, the magnitude of the railway accessibility at the municipal level $\left(A_{i}\right)$ is calculated as follows:

$$
A_{i}=\sum_{K \in\left(d_{i j} \leq d_{0}\right)} R_{j}
$$

where $i$ determines each of the analysed locations, 947 municipalities in our case; $\left(d_{0}\right)$ is the value of the geometric radius, $25 \mathrm{~km} ; R_{j}$ is the variable that determines whether or not the municipality has a railway station, and $K$ is a Kernel function that weights the distance of each municipality located within the $25 \mathrm{~km}$ geometrical radius. In addition, we chose a triangular kernel function to estimate the magnitude of the index, which stands as follows:

$$
f\left(\frac{d_{k j}}{d_{0}}\right)=\left\{\begin{array}{cc}
1-\left|\frac{d_{k j}}{d_{0}}\right| & 0 \leq d_{k j} \leq d_{0} \\
0 & d_{k j}>d_{0}
\end{array}\right.
$$

The Kernel triangular function weights (linearly) down the location of the stations placed within the considered geometric radius $[86,87]$, as established by the parameter $d_{0}$. This procedure adds a spatial delay that smooths the effects of the municipalities with a train station and allows capturing the effects of the proximity to railway networks better.

Despite their limitations, a quick inspection of Figure $3 \mathrm{a}-\mathrm{h}$ shows some aspects of interest. The north-eastern counties, where most of the municipalities with pigmeat processing firms were based by the end of the 19th century, had a pig farming density per area and per inhabitant slightly above the Catalan average. Furthermore, the distance between these localities and Barcelona was shorter than that of the municipalities located in the north-western counties, where the density of pigs was also higher than the Catalan average. These latter counties also had a higher average-altitude and a lower average-temperature 
than the north-eastern Catalan counties. Moreover, the north-western Catalan counties showed a declining demographic trend, like many other municipalities located in the north of the country and far away from the Mediterranean coast. Nevertheless, and as expected, the bulk of the textile industry was located in the east half of Catalonia. Railway accessibility was also better in the country's eastern rather than western part.

However, to construct an index to study the influence of deterministic factors in the location of meat processing firms it is necessary to first determine whether there was any relationship between the municipal location of pigmeat processing firms and the factors and variables we have considered above. To this end, we ran bivariate regressions between the former, the dependent variable, and the latter, which should be considered as the independent variables. The information presented in Table 1 shows that the correlation between the livestock density of the district to which each municipality belongs and the municipal distribution of pigmeat companies in 1896 is positive and statistically significant at the $99 \%$ level. We can conclude the same when this latter variable is correlated with textile industry activity, textile industry trends, the distance between each municipality and Barcelona and the railway accessibility of municipalities. As we might expect from what has been argued above, for the former and the last variables, the sign of the correlation is positive: the more textile activity in a municipality in the mid-19th century, and the closer the railway transport, the higher the probability that meat-processing companies would emerge. Not surprisingly, the correlation is negative for textile industry trends and for distance from Barcelona. In contrast, the pig density per inhabitant and the municipality's altitude do not seem to have any significant influence on the location patterns of the sector. They do not show a statistically significant correlation with the number of meat processing companies per municipality. Instead, the variable on local demographic trends is statistically significant, but only at the $90 \%$ level.

Table 1. Correlation between the municipal distribution of firms in 1896 and some potentially significant variables for determining the initial location of industrial pigmeat processing in late 19th-century Catalonia.

\begin{tabular}{|c|c|}
\hline Variable & Coefficients \\
\hline $\begin{array}{l}\text { Pig density per area } \\
\text { (Number of heads in } 1865 / \mathrm{Km}^{2} \text { ) }\end{array}$ & $0.109 * * *$ \\
\hline $\begin{array}{l}\text { Pig density per capita } \\
\text { (Number of heads in } 1865 / 1000 \text { inhabitants in 1861) }\end{array}$ & -0.013 \\
\hline $\begin{array}{l}\text { Demographic trends } \\
\text { (Population ratio } 1900 / 1857 \text { ) }\end{array}$ & 0.064 * \\
\hline $\begin{array}{l}\text { Textile industry trends } \\
\text { (Cotton loom proportion difference 1931/1861) }\end{array}$ & $-0.655^{* * *}$ \\
\hline $\begin{array}{l}\text { Altitude } \\
\text { (Metres) }\end{array}$ & -0.011 \\
\hline $\begin{array}{l}\text { Textile industry activity } \\
\text { (No. of cotton and wool looms / } 1000 \text { inhabitants in 1861) }\end{array}$ & $0.103 * * *$ \\
\hline $\begin{array}{l}\text { Distance from Barcelona } \\
\text { (Kilometres) }\end{array}$ & $-0.084^{* * *}$ \\
\hline $\begin{array}{l}\text { Railway accessibility } \\
\text { (Distance gradient to the closest train station before 1891) }\end{array}$ & $0.084^{* * *}$ \\
\hline
\end{tabular}

The final steps in the construction of our location index can be summarised as follows. First, we excluded from further consideration those variables that are not statistically significant or have a significance below the $99 \%$ level $(p<0.01)$ when correlated with our dependent variable, the number of pigmeat processing firms at the municipal level.

Second, we standardised the original values of the statistically significant variables to obtain a value ranging between zero and one for all the variables. With the only exception of textile industry trends (cotton loom proportion difference 1931/1861), we carried out the 
standardisation process by dividing the original municipal values, as provided in Figure 3, by the maximum municipal value obtained for each of the five considered variables. With this transformation, the new variable has a range between 0 and 1 . We followed a similar procedure for the case of textile industry trends, but with a preliminary step. Our calculations obtained negative values when the cotton loom proportion was compared between 1861 and 1931. Therefore, we added the minimum municipal value we obtained to all our initial results. For example, consider that the minimum resulting value was -25 . In this case, we added +25 to all our obtained municipal values; as a result, the negative sign disappeared, and then we followed the general standardisation procedure.

Third, once the variables of interest were standardised, we calculated a synthetic index, which we called Apparent Location Suitability Index (ALSI), which can be defined as follows:

$$
\text { ALSI }=(1+\text { pigdenst }) * \frac{1}{(1+\text { distbcnst })} *(1+\text { Loompcst }) * \frac{1}{(1+\text { varloomst })} *(1+\text { railsplag })
$$

where pigdenst is the standardised version of the pig density per area; distbcnst is the standardised version of the Euclidean distance between every municipality and Barcelona; loompcst is the standardised form of the per capita number of looms in the cotton and wool manufacturers in 1861 by municipality; varloomst is the standardised calculation of the variation in the cotton loom proportion difference between 1861 and 1931 by municipality, and railsplag is the standardised form of the municipal distance gradient to the closest train station before 1891. As observed in Equation (3), we increased the value of each variable by one, intending to avoid the zero effect. All variables also have the same weight in this index. Moreover, in Equation (3), we included the variables that negatively correlated with the number of meat processing firms by municipality in an inverted form. By applying the same procedure described above, we finally standardised the results obtained in Equation (3) to range between 0 and 1 .

We also estimated a weighted index where pig density plays a more critical role by departing from the former index. The reason was that meat processing was a productive activity with low technological content, and, therefore, the endowment of essential inputs was of primary importance. In other words, sausage production was not a complex activity but a relatively simple one, albeit very dependent on the regular supply of meat, the industry's central and essential raw material [54]. To consider this, we estimated a second index that squares the weight we give to municipal livestock availability as a location factor. The new weighted ALSI takes the form shown below, which, once calculated, we also standardised to be between 0 and 1 :

$$
\text { ALSI }=(1+\text { pigdenst })^{2} * \frac{1}{(1+\text { distbcnst })} *(1+\text { Loompcst }) * \frac{1}{(1+\text { varloomst })} *(1+\text { Railsplag })
$$

Table 2 and Figures 4 and 5 show the values of the ALSI, in its unweighted and weighted forms. Figure 4 provides evidence for all municipalities. Table 2 details ALSI values for those municipalities with meat-processing firms in 1896. Figure 5 organises the previous evidence into two categories: first, municipalities with an ALSI above or below the mean ALSI value; second, municipalities with an ALSI above the ALSI value for the municipality of Vic. In addition, it identifies the municipalities with meat-processing firms in 1896. 

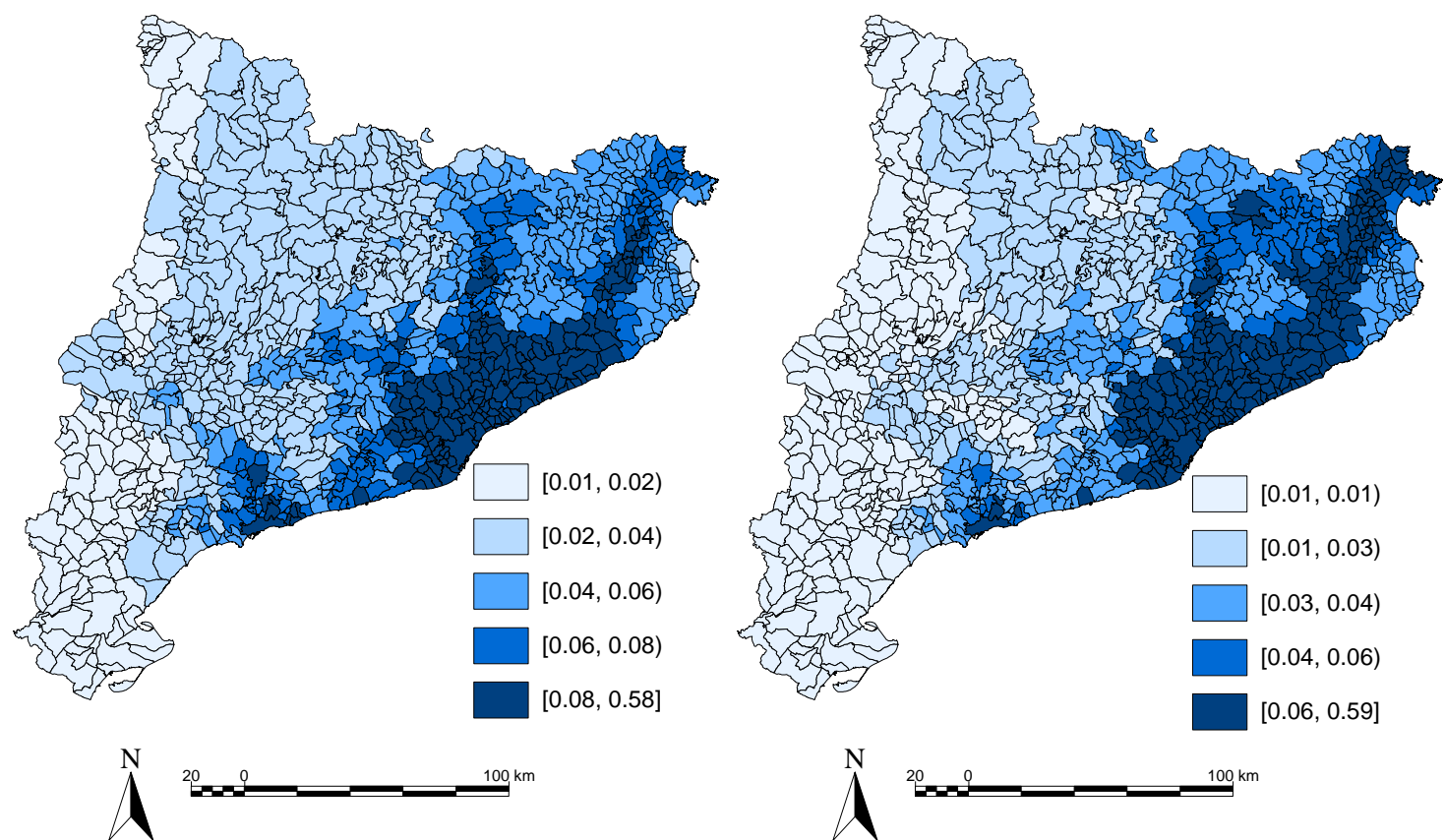

(a)

(b)

Figure 4. The Apparent Location Suitability Index (ALSI). Notes and sources: See Figure 3 and text. (a) Unweighted ALSI. (b) Weighted ALSI.

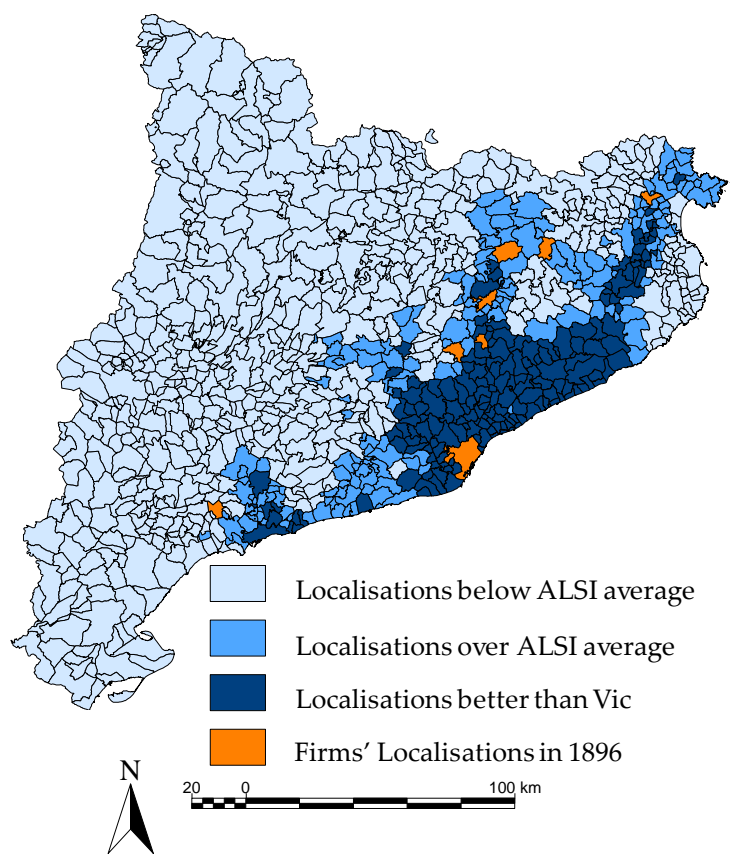

(a)

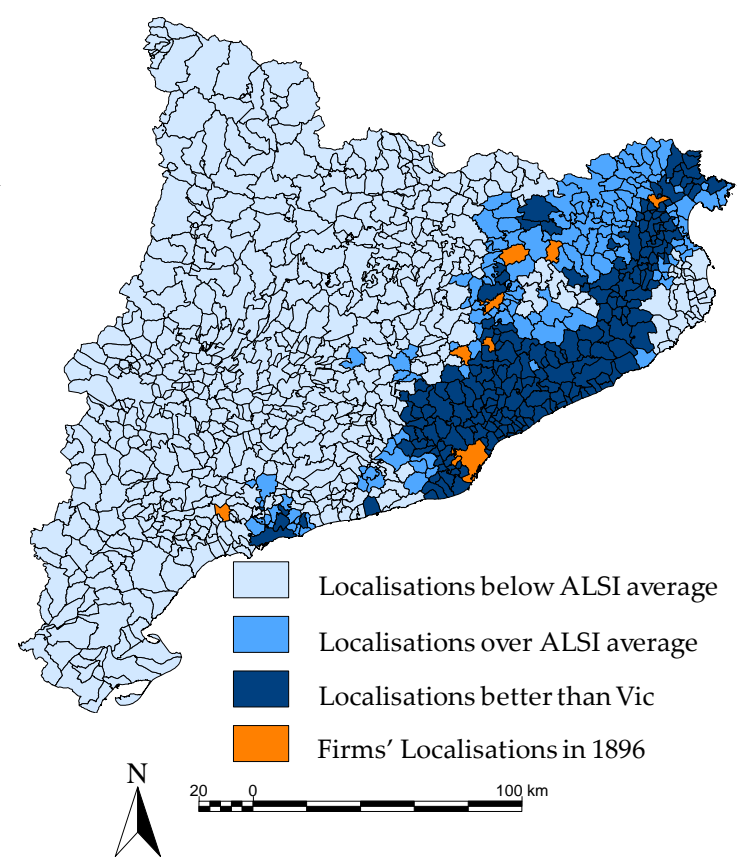

(b)

Figure 5. The Apparent Location Suitability Index (ALSI) and the firms' location in the Catalan meat-processed industry in the second half of the 19th century. Notes and sources: See Figures 2 and 3. (a) Unweighted ALSI and firms' location. (b) Weighted ALSI and firms' location. 
Table 2. The Apparent Location Suitability Index (ALSI) in the municipalities of Catalonia with meat processing firms in 1896.

\begin{tabular}{|c|c|c|c|c|c|c|}
\hline \multicolumn{7}{|c|}{ Panel 2.1. Unweighted ALSI } \\
\hline Municipality & County & Province & $\begin{array}{l}\text { Number } \\
\text { of Firms }\end{array}$ & Index & $\begin{array}{l}\text { Ordinal Position } \\
\text { (Out of 9) }\end{array}$ & $\begin{array}{l}\text { Ordinal Position } \\
\text { (Out of 947) }\end{array}$ \\
\hline Barcelona & Barcelonès & Barcelona & 6 & 0.582 & 1 & 1 \\
\hline Vic & Osona & Barcelona & 5 & 0.075 & 5 & 187 \\
\hline Castellterçol & Moianès & Barcelona & 2 & 0.113 & 4 & 80 \\
\hline L'Aleixar & Baix Camp & Tarragona & 2 & 0.034 & 9 & 563 \\
\hline Centelles & Osona & Barcelona & 1 & 0.127 & 3 & 47 \\
\hline Figueres & Alt Empordà & Girona & 1 & 0.073 & 6 & 201 \\
\hline Sant Feliu de Pallerols & Garrotxa & Girona & 1 & 0.054 & 8 & 340 \\
\hline Sant Just Desvern & Baix Llobregat & Barcelona & 1 & 0.128 & 2 & 43 \\
\hline Sant Pere de Torelló & Osona & Barcelona & 1 & 0.067 & 7 & 230 \\
\hline \multicolumn{7}{|c|}{ Panel 2.2. Weighted ALSI } \\
\hline Municipality & County & Province & $\begin{array}{l}\text { Number } \\
\text { of Firms }\end{array}$ & Index & $\begin{array}{l}\text { Ordinal Position } \\
\text { (Out of 9) }\end{array}$ & $\begin{array}{l}\text { Ordinal Position } \\
\text { (Out of 947) }\end{array}$ \\
\hline Barcelona & Barcelonès & Barcelona & 6 & 0.589 & 1 & 1 \\
\hline Vic & Osona & Barcelona & 5 & 0.056 & 6 & 225 \\
\hline Castellterçol & Moianès & Barcelona & 2 & 0.101 & 2 & 42 \\
\hline L'Aleixar & Baix Camp & Tarragona & 2 & 0.022 & 9 & 561 \\
\hline Centelles & Osona & Barcelona & 1 & 0.090 & 3 & 63 \\
\hline Figueres & Alt Empordà & Girona & 1 & 0.067 & 5 & 153 \\
\hline Sant Feliu de Pallerols & Garrotxa & Girona & 1 & 0.054 & 7 & 236 \\
\hline Sant Just Desvern & Baix Llobregat & Barcelona & 1 & 0.086 & 4 & 80 \\
\hline Sant Pere de Torelló & Osona & Barcelona & 1 & 0.051 & 8 & 264 \\
\hline
\end{tabular}

Notes and Sources: See Figures 2 and 3.

\section{Results: Determinism, Contingency, and Agency in the Genesis of the Pigmeat Processing Clusters}

What explains the genesis of clusters and industrial districts? Why do they originate and prosper in certain areas and not in others? In both their unweighted and weighted forms, our estimates show that the municipalities with the highest ALSI values were mostly located around central-coastal and north-eastern Catalonia (Figure 4), in areas with a relatively high density of pigs, but also closer to railway lines and not very far away from Barcelona (Figure 3). In addition, the pre-existing commercial networks associated with the textile activity and abundance of labour supply due to a declining textile activity reinforced the above location patterns.

In short, by combining supply and demand factors, there was a particular part of Catalonia where it was more probable that the meat processing industry would originate and develop. It was indeed in these areas where these municipalities with meat processing firms were located by the end of the 19th century (Figure 5). Therefore, we might then conclude that deterministic factors played a central role in the origins and early development of the meat clusters in 19th century Catalonia: Barcelona, Vic, Castellterçol, Centelles, Figueres, Sant Feliu de Pallerols, Sant Just Desvern, and Sant Pere de Torelló were municipalities where the new meat processing industry could be expected to emerge. The only exception to this general rule was the municipality of l'Aleixar, in south-eastern Catalonia. Although it was close to the only area with the highest livestock density in the province of Tarragona (Figure 3), this municipality had a low suitability index, insufficient to be included among the locations with a higher probability of meat processing firms appearing (Table 2, Figures 4 and 5).

If deterministic factors were clearly at work, discretionary and contingency factors were also present in the location of the meat processing industry. Figure 5 elaborates on this issue. First, it shows that of the 947 current Catalan municipalities, more than 360 had an ALSI value above the Catalan mean in the late-19th century; however, industrial meat 
processing firms emerged in only eight of them. Second, it can be clearly seen, alongside Table 2, that these eight municipalities were not always the $a$ priori best-suited areas to expect meat processing companies to emerge and develop; Barcelona is the only exception to this rule. For example, according to the ASLI indicator, the municipality of Vic, which was home to five companies in the late-19th century, ranked 187 (unweighted index) and 225 (weighted index), respectively. This means that, relative to Vic, there were around 200 places that would have been better to locate the new meat activity. Third, and regarding this latter locality, of the municipalities where meat processing firms emerged, between 4 and 5 of them had an ASLI value above Vic, which, nevertheless, evolved to become a leading pigmeat processing cluster.

To sum up, the previous evidence suggests that although deterministic factors were central in influencing the initial location of the meat processing activity, there was also a contingent element of indeterminacy prior to the consolidation of a cluster. Thus, if we had to predict a specific and delimited area for the emergence of an industrial meat processing cluster, it would not have been an easy task to get the choice right. Furthermore, it would have been even more difficult if we were trying to guess the exact district that would lead the new and emerging meat processing industry. This explains why it is relevant to consider the existence of windows of locational opportunity (WLO) in the formation of clusters, including sectors with low technological content, as in our case study.

An example of this can be found in Vic. The questions can be posed in quite a simple way. If the factors that gave rise to the Vic cluster were also present in other locations, in some cases even more intensively, why did the Vic meat processing district become consolidated and eventually thrive? The literature on WLOs suggests that, among other things, the human agency may prove to be a critical factor in the early development of an industrial district. Recent literature on regional development points in the same direction (e.g., [88]). Although more research is needed, we cannot rule out this potential explanation. Indeed, for the specific case of Vic, there is evidence suggesting that the role of human agency was important. Interestingly, this seems to have been especially true in the 1870s, when the district had already achieved particular relevance but was still halfway between its proto-industrial stage and the beginnings of factory organisation.

Indeed, as the formation of the Vic district was progressing, various initiatives, linked to human agency contributed to its consolidation. Thus, for example, the publication of a play, 'Les llonganisses de Vic' (The Vic sausages) by Josep Serra i Campdelacreu (1869) [89], writer, archivist, and local chronicler, deserves special mention, as it made the product known beyond the local borders. Particular mention also goes to the winning work of the competition organised by the Vic Literary Circle in 1870. Interestingly, the winning work had a title very similar to Serra's play, although the focus differed. This work, authored by Dr Joaquim Salarich [90] and entitled 'El salchichón de Vic' (The Vic sausage), set out various arguments for promoting the meat processing industry, which, according to its author, was to become a source of wealth for the city. Salarich had in mind, as he explicitly stated, the cases of Cincinnati and Chicago in the USA, two leading centres for pigmeat processing (e.g., [79-82]). In the context of the economic and demographic crisis that we mentioned above, the interest of the local authorities and institutions in such a study should come as no surprise.

However, the most outstanding example of human agency is related to the action of Jaume De Vernis, a merchant and industrialist of the town and probably one of the key figures in the early development of the industrial district of Vic. He took the initiative to participate and promote the Vic sausage at the International Exhibition in Philadelphia in 1876, and he also prepared the town's participation in the 1878 Paris Exhibition. De Vernís also became the town's mayor between 1879 and 1883, and again in 1884, although for a shorter period [91]. He received support from the city's meat processors in taking the mayor's office; at least, this is what the newspaper La Vanguardia reported in a critical tone.

Founded in 1881 and linked to the Liberal Party, La Vanguardia stated that "hay que advertir que monseñor De Vernis es rechazado por toda la población, excepto unos cuantos 
carniceros, compañeros de oficio de don Jaime, que quieren á uno de la clase al frente del Municipio" ["it should be noted that Mr De Vernis is rejected by the entire population, except for a few butchers, colleagues of Don Jaime's trade, who want that one of their class heads the municipality"]. What is certain is that De Vernis undertook critical actions to publicise the local sausage. In addition, as the town's mayor, he took the necessary steps to give the sausage industry privileged fiscal treatment from the local administration. The literature identifies actions like those carried out by De Vernis as activities and roles that characterise cluster facilitators (e.g., [21,92-97]). De Vernis' activity can also be linked to the literature that analyses the contribution of leadership to city and regional development (e.g., [98]). The actions of cluster facilitators often take place in a more institutionalised context, in the form of business associations, for example. Nevertheless, De Vernis' policy was equally helpful for promoting the district.

Despite their disparity, the initiatives developed by Serra, Salarich and, above all, De Vernis made the city and the product well-known, especially outside the region. They also aroused the interest of consumers and producers. As a result, these initiatives also fostered a process of attraction of an exogenous nature, starred by entrepreneurs who were searching for new locations and new areas for investment. A pioneering case was that of the firm Torra, San y Compañía, which years later would become Robert y Compañía, probably the first company with foreign capital (from Barcelona), set up in 1881 and fully operational two years later.

There were other initiatives during the 1880s. By 1886, we have the first complete annual register of entries of lean meat. It lists eight companies that declared an overall entry into the town of 201 metric tonnes of meat. These companies were partly local and partly Barcelona-based, and they were very different in size: the abovementioned Robert y Compañía, for example, reported an annual use of meat for sausage production of around $82,000 \mathrm{~kg}$, while Josep Parareda, funded through local capital, recorded only $1200 \mathrm{~kg}$ of meat per year. What is interesting to note is that, in its early stage, the district combined locally based endogenous dynamics, whose roots are to be found in a previous proto-industrial process, with an exogenous-based mechanism linked to the attraction of foreign capital. As a result, by the 1880s, the district seemed to be solidly formed, and it already had a distinctly industrial character. Notably, human agency seems to have played a non-negligible role in the cluster's formation and final consolidation.

On the other hand, the formation of the Vic district impacted the Catalan meat processing industry as a whole. It was probably influenced by location processes and production dynamics that had arisen in other Catalan municipalities, which, interestingly, were also located in north-eastern Catalonia.

The case of Olot provides an excellent example of how Vic had an impact on other production areas. Olot could have undergone a process similar to that experienced by Vic, as was the case some decades later. Interestingly, the results of our estimates for Olot yield an ALSI value of 0.068 (unweighted) and 0.065 (weighted), and it ranks 227 and 165 (out of 947 municipalities), respectively. These figures suggest that this municipality was placed in an area with a very-high probability of pigmeat processing firms emerging. Nevertheless, this was not initially the case. The intense competition from Vic determined Olot's early development, and meat processing did not go beyond its artisanal stage, as argued by the Junta Consultiva Agronómica [Agricultural Advisory Board] (1892: 379) [99]. This board, formed by engineers [100], pointed out that Olot's salted bacon and sausages "se expenden para varios puntos del Principado, llegando ( . . ) no sólo á los mercados de la Penínsulasí que también á los de Ultramar" ["are sold in various parts of Catalonia, reaching ( . . ) not only the markets of the Iberian Peninsula but also those of overseas"]. However, despite this, Olot's meat industry "no se halla muy extendida por la competencia que tienen en Vich" ["is not very widespread due to the competition with Vic"].

From the 1880s to the early 1920s, the Vic meat processing cluster experienced an upward trend, which would correspond to a phase of growth and development in the cluster's life cycle [54]. The number of companies that declared meat inputs went from 8 
in 1886 to 12 in 1906. In 1909, there were already 13 manufacturing facilities, and, finally, in 1915 , the number of firms involved in the meat processing industry amounted to 17. Between 1886 and 1905, the district's productive capacity had grown at a cumulative annual rate of $5.4 \%$; between 1906 and 1915, this growth rate was 8.5\% [101].

The analysis of this phase of growth is beyond the scope of this paper; however, it is worth noting that this stage also shows similar dynamics to those described by the WLO approach. According to Storper and Walker (1989: 71) [12], "industries are capable of generating their own conditions of growth in place, by making factors of production come to them or causing factor supplies to come into being where they did not exist before. Capitalism is capable of escaping from the past to create new localizations of industry". In other words, once established in the territory, the industry generates those factors that will allow it to grow.

This self-generation of factors is what also happened in the Vic district. The external economies, which characterise business agglomerations, were driving the development of the Vic cluster. At the same time, industrial growth, probably through external pecuniary economies, favoured livestock growth, creating an interaction between the meat industry and pig farming that was extraordinarily positive for the development and competitiveness of this agro-industrial cluster. In fact, in the years of the First World War, Vic had also become the Catalan district with the largest number of pigs (Figure 6). Once it originated, the district began generating its growth factors, attracting a fundamental factor to a nearby location; that is, it attracted the pigs that were to provide the necessary meat for an expanding sausage industry.

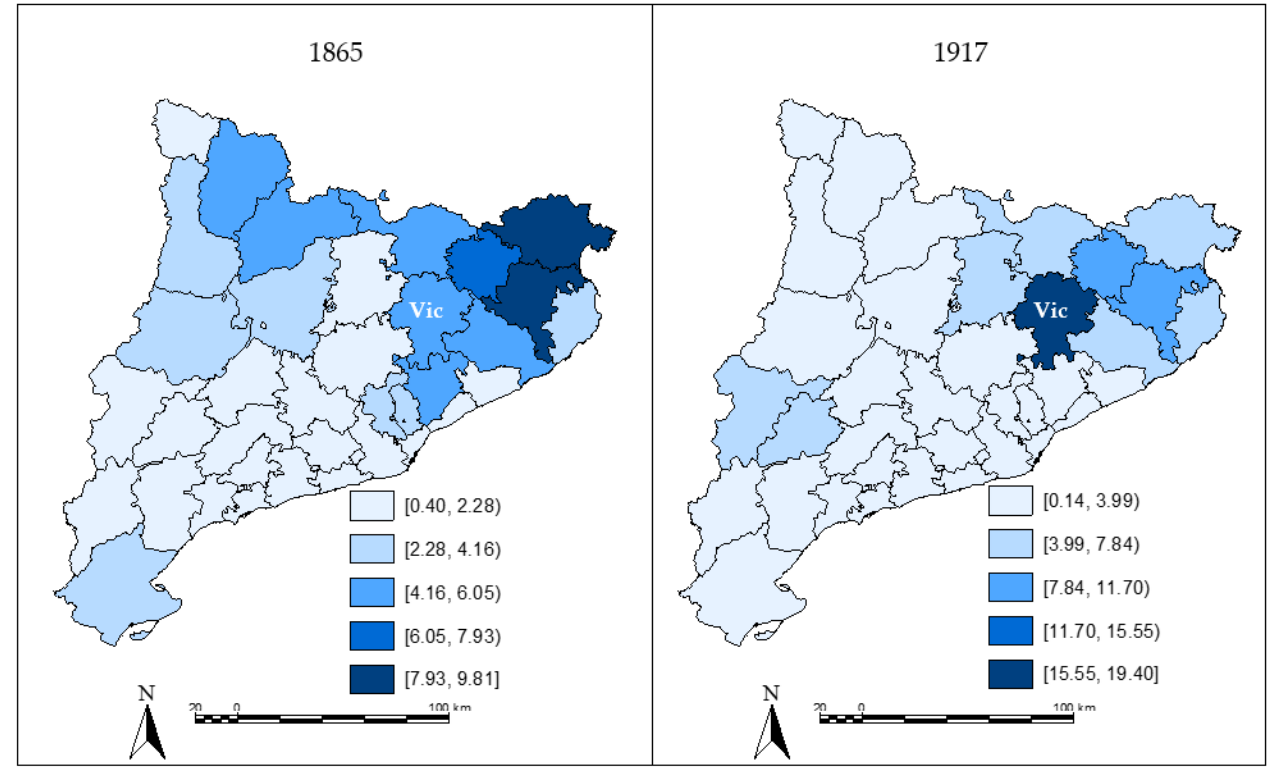

Figure 6. Pig distribution in Catalonia by districts, 1865 and 1917 (in percentages). Notes and Source: Authors' own elaboration based on $[46,55,102]$. Adjustments in changing boundaries have been taken into consideration when necessary.

Finally, due to its dynamism, the Vic district ended up leading the pigmeat processing industry in Catalonia and, to a certain extent, in Spain. In 1910, the taxes paid by the meat companies located in the town of Vic accounted for $77.4 \%$ of the total taxes paid in Catalonia for the production of sausages. This percentage was $23.4 \%$ when the taxes paid by Vic meat producers are compared with those paid in Spain for the same concept.

\section{Conclusions}

This research aimed to contribute to a better understanding of the genesis of agroindustrial clusters in Catalonia during the second half of the 19th century. We have focused 
on pigmeat processing and paid particular attention to its leading and most successful agro-industrial complex until at least the early 1920s: the Vic meat cluster.

The central contribution of this work has been to identify the main factors that explain the location and origins of pigmeat agro-industrial clusters across the territory. We have found that deterministic factors played a crucial and probably leading role as they determined the most appropriate area for the location of firms. Based on the case of Vic and thanks to the construction of a new index of industrial location at the municipal level, we conclude that the central-coastal and north-eastern parts of Catalonia had the highest probability that pigmeat processing industrial firms would emerge in the last decades of the 19th century. The advantages of these areas combined supply and demand factors, including a high density of pigs, relative abundance of an unemployed labour force, preexistence of commercial networks, proximity to the main centre of demand, and access to the railway network. Interestingly, by the end of the 19th century all except one of the municipalities with industrial pigmeat processing firms were located in central-coastal and north-eastern Catalonia.

Nevertheless, our findings have also revealed that contingent factors cannot be neglected if we want to obtain a more comprehensive picture of industrial location. The index we have constructed has shown that many municipalities did not have any meat processing firms despite being a priori better suited for developing industrial meat processing than those where this new industry was finally located. Of these latter municipalities, Vic itself was not among those that were better endowed though it became a leading cluster in the sector. We have dealt with this apparent paradox by considering non-deterministic factors in analysing the origins of the meat clusters, as suggested by the Window of Locational Opportunity (WLO) approach. In particular, and using Vic as a case study, we found evidence showing that human agency should be considered as an additional, non-negligible, explanatory factor in cluster genesis and early development.

Although our analysis is limited to a specific region and industry, we have also provided new evidence on more general issues on the origins of clusters. First, we have developed a methodology and a new index of apparent location suitability, which, despite their limitations, could be extended to study the origins of other agribusiness clusters. One limitation of the index is that it is unable to capture opportunity costs across sectors. For example, pigmeat processing might have to compete with other activities using similar resources already established in the territory, which would limit location options. Future research needs to develop this issue further.

Second, we have shown the general usefulness of the window of locational opportunity concept. Traditional and more recent studies have analysed the emergence of new clusters and the entry in sectors with high technology content (e.g., [103,104]). Nevertheless, our case study illustrates that the WLO concept can also be applied to better understand the location process in industries characterised by low-technological content, as was the case of pigmeat processing in the second half of the 19th century in Catalonia. It is true that, our methodology has not been designed to quantify the relative importance of deterministic relative to non-deterministic factors in an industrial location, as we have not intended either to disentangle the main explanations that prevail in the analysis of the determinants of industrial location, i.e., those more in line with the Heckscher-Ohlin theorem and those associated with the New Economic Geography. This lack of quantification can be considered an additional limitation in our analysis, and, if possible, this should be addressed in future research. Nevertheless, we have provided sound and fresh evidence to conclude that deterministic factors resulting from the interaction of factor endowments and market access significantly constrained industry location options; We have also shown that within these general constraints, there was non-negligible room for probabilistic and contingent factors, and have been able to identify human agency.

Third, we have, therefore, placed this study in the interplay of different literatures for addressing the phenomenon of the origins of agglomerations. This included the cluster life cycle approaches, a conventional analysis of industrial location, evolutionary perspectives 
on the role of contingency, and studies on agency. We believe that rather than contradictory or lacking in focus, it is very fruitful to connect different but related approaches and traditions. In this vein, our case study is instructive regarding the relevance of the interaction between deterministic factors, contingency, and human agency in explaining the location, birth, and early development of clusters.

Finally, although we have not addressed the emergence of agribusiness clusters in rural areas and their potential for rural development directly, our case study illustrates the importance of considering supply in combination with demand factors in the birth of agribusiness. Indeed, the supply factors are not the only ones that are considered as locational determinants for this industry. The new industrial firms emerged in Vic, taking advantage of the relatively easy access to the rural sources of supply and the urban sources of demand. For this combination to be possible, transport infrastructures were essential. The lack of a balanced combination due to poor transport infrastructure can prevent the emergence of agribusiness firms in rural areas, as some recent studies in developing countries have shown (e.g., [105]). In the end, the locational decisions of companies and the emergence (or lack) of agribusiness clusters influence rural development.

Author Contributions: P.C. contributed with conceptualization, methodology, formal analysis, research, resources, data curation, writing —original draft preparation, writing - review and editing, visualisation, supervision, and funding acquisition. R.R.-M. contributed with conceptualization, methodology, formal analysis, research, resources, data curation, writing — original draft preparation, writing-review and editing, visualisation, supervision, and funding acquisition. All authors have read and agreed to the published version of the manuscript.

Funding: This paper forms part of the research project PGC 2018-093896-B-I00 'Mediterranean capitalism? Successes and failures of industrial development in Spain, 1720-2020', funded by the Ministerio de Ciencia e Innovación (Madrid), MCIN/AEI/10.13039/501100011033; and by the European Regional Development Fund, "ERDF A way of making Europe”.

Institutional Review Board Statement: Not applicable.

Informed Consent Statement: Not applicable.

Data Availability Statement: Not applicable.

Acknowledgments: An early version of this paper was presented at the workshop 'Economías de aglomeración y desarrollo rural: innovación, competitividad e internacionalización frente a la despoblación' [Agglomeration economies and rural development: innovation, competitiveness, and internationalisation in the face of depopulation], Universidad de Extremadura, May 2021. We thank the participants and organizers of this workshop, as well as the journal's editors and three anonymous referees for their useful comments and suggestions. The usual disclaimer applies.

Conflicts of Interest: The authors declare no conflict of interest.

\section{References}

1. Wilson, J.F.; Popp, A. (Eds.) Industrial Clusters and Regional Business Networks in England, 1750-1970, 1st ed.; Ashgate: Aldershot, UK, 2003.

2. $\quad$ Becattini, G.; Bellandi, M.; De Propris, L. (Eds.) A Handbook of Industrial Districts, 1st ed.; Edward Elgar: Cheltenham, UK, 2009.

3. Catalan, J.; Miranda, J.A.; Ramon-Muñoz, R. (Eds.) Distritos y Clusters en la Europa del Sur, 1st ed.; LID Editorial: Madrid, Spain, 2011.

4. Marshall, A. Principles of Economics, 1st ed.; Macmillan and Co.: London, UK, 1890.

5. Marshall, A. Industry and Trade, 1st ed.; Macmillan and Co.: London, UK, 1919.

6. Becattini, G. Dal settore industriale al distretto industriale. Alcune considerazioni sull'unità di indagine dell'economia industriale. L'Ind. Riv. Ec. Pol. Ind. 1979, 5, 7-21.

7. Becattini, G. Mercato e Forze Locali: Il Distretto Industriale, 1st ed.; Il Mulino: Bologna, Italy, 1987.

8. Sabel, C.F.; Zeitlin, J. Historical Alternatives to Mass Production: Politics, Markets and Technology in Nineteenth-Century Industrialization. Past Present 1985, 108, 133-176. [CrossRef]

9. Porter, M.E. Clusters and the New Economics of Competition. Harv. Bus. Rev. 1998, 76, 77-90. [PubMed]

10. Porter, M.E. Location, Competition, and Economic Development: Local Clusters in a Global Economy. Econ. Dev. Q. 2000, 14, 15-34. [CrossRef] 
11. Porter, M.E. Location, Clusters and Company Strategy. In The Oxford Handbook of Economic Geography, 1st ed.; Clark, G.L., Feldman, M.P., Gertler, M.S., Eds.; Oxford University Press: Oxford, UK, 2000; pp. 253-274.

12. Molema, M.; Segers, Y.; Karel, E. Introduction: Agribusiness Clusters in Europe, 19th and 20th Centuries. Tijdschr. Soc. Econ. Geschied. 2016, 13, 1-16. [CrossRef]

13. United Nations Industrial Development Organization, UNIDO. Industrial Cluster and Poverty Reduction: Towards a Methodology for Poverty and Social Impact Assessment of Cluster Development Initiatives; UNIDO: Vienna, Austria, 2004.

14. Gálvez-Nogales, E. Agro-based clusters in developing countries: Staying competitive in a globalized economy. In Marketing and Finance Occasional Paper; United Nations: Rome, Italy, 2010; Volume 25, pp. 1-105.

15. Martinidis, G.; Adamseged, M.E.; Dyjakon, A.; Fallas, Y.; Foutri, A.; Grundmann, P.; Hamann, K.; Minta, S.; Ntavos, N.; Råberg, T.; et al. How Clusters Create Shared Value in Rural Areas: An Examination of Six Case Studies. Sustainability 2021, 13, 4578. [CrossRef]

16. Menzel, M.P.; Fornahl, D. Cluster Life Cycles-Dimensions and Rationales of Cluster Evolution. Ind. Corp. Chang. 2010, 19, 205-238. [CrossRef]

17. Popp, A.; Wilson, J. Life cycles, contingency, and agency: Growth, development, and change in English industrial districts and clusters. Environ. Plan. A 2007, 39, 2975-2992. [CrossRef]

18. Klepper, S. Industry life cycles. Ind. Corp. Chang. 1997, 6, 145-182. [CrossRef]

19. Swann, G.M.P. Towards a Model of Clustering in High Technology Industries. In The Dynamics of Industrial Clusters, 1st ed.; Swann, G.M.P., Prevezer, M., Stout, D., Eds.; Oxford University Press: Oxford, UK, 1998; pp. 52-76.

20. Bergman, E.M. Cluster life-cycles: An emerging synthesis. In Handbook of Research on Cluster Theory, 1st ed.; Karlsson, C., Ed.; Edward Elgar: Cheltenham, UK, 2008; pp. 114-132.

21. Ingstrup, M.B.; Damgaard, T. Cluster Facilitation from a Cluster Life Cycle Perspective. Eur. Plan. Stud. 2013, 21, 556-574. [CrossRef]

22. Menzel, M.P.; Henn, S.; Fornahl, D. (Eds.) Emerging Clusters-Theoretical, Empirical and Political Perspectives on the Initial Stage of Cluster Evolution; Edward Elgar: Cheltenham, UK, 2010.

23. Storper, M.; Walker, R. The Capitalist Imperative; Territory, Technology and Industrial Growth, 1st ed.; Basil Blackwell: New York, NY, USA, 1989.

24. Boschma, R. The window of locational opportunity-concept. Quad.-Work. Pap. DSE (Alma Mater Studiorum-Univ. Di Bologna Dip. Di Sci. Econ. Bologna Italy) 1996, 60, 1-35.

25. Generalitat de Catalunya. Promotora dels Aliments Catalans (Prodeca). The Catalan Agri-Food Sector. Available online: https://www.prodeca.cat/en/sectors/the-catalan-agri-food-sector (accessed on 25 January 2022).

26. Sölvell, Ö. Clusters: Balancing Evolutionary and Constructive Forces, 1st ed.; Ivory Tower Publishers: Stockholm, Sweden, 2008.

27. Kim, S. Expansion of markets and the geographic distribution of economic activities: The trends in U.S. regional manufacturing structure, 1860-1987. Q. J. Econ. 1995, 110, 881-908. [CrossRef]

28. Tirado, D.A.; Paluzie, E.; Pons, J. Economic integration and industrial location: The case of Spain before World War I. J. Econ. Geogr. 2002, 2, 343-363. [CrossRef]

29. Rosés, J.R. Why isn't the whole of Spain industrialized? New economic geography and early industrialization, 1797-1910. J. Econ. Hist. 2003, 63, 995-1022. [CrossRef]

30. Crafts, N.; Mulatu, A. What explains the location of industry in Britain, 1871-1931? J. Econ. Geogr. 2005, 5, 499-518. [CrossRef]

31. Wolf, N. Endowments vs. market potential: What explains the relocation of industry after the Polish reunification in 1918? Explor. Econ. Hist. 2007, 44, 22-42. [CrossRef]

32. Martínez-Galarraga, J. The determinants of industrial location in Spain, 1856-1929. Explor. Econ. Hist. 2012, 49, 255-275. [CrossRef]

33. Badia-Miró, M. Spatial Inequality in Chile in the Long Run: A Paradox of Extreme Concentration in the Absence of Agglomeration Forces (1890-2017). In Time and Space. Latin American Regional Development in Historical Perspective, 1st ed.; Tirado-Fabregat, D.A., Badia-Miró, M., Willebald, H., Eds.; Palgrave Macmillan: Cham, Switzerland, 2020; pp. 157-182.

34. Krugman, P. Geography and Trade, 1st ed.; MIT Press: Cambridge, MA, USA, 1991.

35. Scott, A.; Storper, M. High technology industry and regional development: A theoretical critique and reconstruction. Int. Soc. Sci. J. 1987, 112, 215-232.

36. Boschma, R.A. New industries and windows of locational opportunity. A long-term analysis of Belgium. Erdkunde 1997, 51, 12-22. [CrossRef]

37. Boschma, R.A.; Lambooy, J.G. Evolutionary economics and economic geography. J. Evol. Econ. 1999, 9, 411-429. [CrossRef]

38. Boschma, R.A.; van der Knaap, B. New technology and windows of locational opportunity. In Economics and Evolution; Reijnders, J., Ed.; Edward Elgar: Cheltenham, UK, 1997; pp. 171-202.

39. Boschma, R. Path creation, path dependence and regional development. In Path Dependence and the Evolution of City Regional Economies; Simmie, J., Carpenter, J., Eds.; Oxford Brookes University: Oxford, UK, 2007; pp. 40-55.

40. Jacobs, J. The Economy of Cities, 1st ed.; Random House: New York, NY, USA, 1969.

41. Iammarino, S.; McCann, P. The structure and evolution of industrial clusters: Transactions, technology and knowledge spillovers. Res. Policy 2006, 35, 1018-1036. [CrossRef]

42. Weber, A. Über den Standort der Industrien, 1st German ed.; J. C. B. Mohr: Tübingen, Germany, 1909. Translated and edited by C. J. Friedrich as Alfred Weber's Theory of the Location of Industries, 1st English ed.; University of Chicago Press: Chicago, IL, USA, 1929. 
43. Lambert, D.M.; McNamara, K.T. Location determinants of food manufacturers in the United States, 2000-2004: Are nonmetropolitan counties competitive? Agric. Econ. 2009, 40,617-630. [CrossRef]

44. Eurostat. Nomenclature of Territorial Units for Statistics (NUTS). Nuts Maps. Available online: https://ec.europa.eu/eurostat/ web/nuts/nuts-maps (accessed on 20 February 2021).

45. Generalitat de Catalunya. Institut Cartogràfic i Geològic de Catalunya. Mapes Municipals. Available online: https://www.icgc. cat/L-ICGC/Sobre-1-ICGC/Recursos-didactics/Mapes-de-comarques (accessed on 10 January 2021).

46. Generalitat de Catalunya. Institut Cartogràfic i Geològic de Catalunya. Mapes Municipals. Available online: https://www.icgc. cat/Administracio-i-empresa/Descarregues/Capes-de-geoinformacio/Mapes-municipals (accessed on 10 January 2021).

47. Nadal, J. La indústria cotonera. In Història Econòmica de la Catalunya Contemporània. Segle XIX. Indústria. Transports i Finances, 1st ed.; Nadal, J., Maluquer de Motes, J., Sudrià, C., Cabana, F., Eds.; Fundació Enciclopèdia Catalana: Barcelona, Spain, 1991; Volume 3, pp. 13-86.

48. Benaul, J.M. La llana. In Història Econòmica de la Catalunya Contemporània. Segle XIX. Indústria. Transports i Finances, 1st ed.; Nadal, J., Maluquer de Motes, J., Sudrià, C., Cabana, F., Eds.; Fundació Enciclopèdia Catalana: Barcelona, Spain, 1991; Volume 3, pp. 87-158.

49. Nadal, J.; Benaul, J.M. La formació d'una societat industrial, 1833-1936. In Atles de la Industrialització de Catalunya, 1750-2010, 1st ed.; Nadal, J., Benaul, J.M., Sudrià, C., Eds.; Vicens Vives: Barcelona, Spain, 2012; pp. 54-159.

50. Albareda, J. La Industrialització a la Plana de Vic (1770-1875), 1st ed.; Publicacions del Patronat d'Estudis Ausonencs: Vic, Spain, 1981.

51. Generalitat de Catalunya. Institut d'Estadística de Catalunya (Idescat). Demographic Historical Series. Municipalities. Available online: https:/ / www.idescat.cat/ (accessed on 15 February 2021).

52. Espluga, X. Trajectòries Locals d'industrialització. Aproximació a la Història Industrial de Girona, Olot, Berga i Manresa (1714-1913). Unpublished Master's Thesis, Universitat de Barcelona, Barcelona, Spain, 1998.

53. Segret, R. La Fàbrica d'embotits de cal Sala. Una de les Indústries de la vila de Sant Llorenç de Morunys al Segle XX; Quaderns de la Confraria dels Colls-Gràfiques Muval: Solsona, Spain, 2016.

54. Castell, P. Els inicis de la indústria càrnia a Osona (1850-1920). Est. Hist. Agric. 2001, 14, $255-294$.

55. Giralt, E. "L'agricultura”. In Història Econòmica de la Catalunya Contemporània. Segle XIX. Població i Agricultura; Nadal, J., Maluquer de Motes, J., Sudrià, C., Cabana, F., Eds.; Fundació Enciclopèdia Catalana: Barcelona, Spain, $1990 ;$ Volume 2, pp. $121-305$.

56. Nicolau, R.; Pujol, J. El consumo de proteínas animales en Barcelona entre las décadas de 1830 y 1930 : Evolución y factores condicionantes. Inv. Hist. Ec. 2005, 3, 101-134.

57. Guàrdia, M.; Oyón, J.L.; Garriga, S.; Fava, N. Meat consumption and nutrition transition in Barcelona, 1709-1935. Urban Hist. 2018, 45, 193-213. [CrossRef]

58. Kriedte, P.; Medick, H.; Schlumbohm, J. Industrialization before Industrialization, 1st English ed.; Cambridge University Press: Cambridge, UK, 1981

59. Ponce, S. Ferrocarril, agricultura i mercat. Els efectes del transport ferroviari a l'economia d'Osona (1875-1924). Est. Hist. Agric. 1992, 9, 127-156.

60. Ponce, S. Transformacions Agrícoles $i$ Canvi Social a la Comarca d'Osona. (Segles XVIII-XX), 1st ed.; Eumo Editorial: Vic, Spain, 1999.

61. Ponce, S. El procés d'especialització ramadera a la Plana de Vic (1850-1930). Est. Hist. Agric. 2001, 14, 185-196.

62. Garrabou, R. La crisi agraria espanyola de finals del segle XIX: Una etapa del desenvolupament del capitalisme. Recerques 1975, 5, 163-216.

63. Garrabou, R.; Pujol, J. El canvi agrari a la Catalunya del segle XIX. Recerques 1987, 19, 35-83.

64. GEHR, Grupo de Estudios de Historia Rural. Contribución al análisis histórico de la ganadería española, 1865-1929. Agric. Y Soc. 1978, 8, 129-182.

65. Pujol Andreu, J. Especialització i canvi tècnic en l'expansió del sector ramader català entre 1880 i 1936. Recerques 1998, 37, 31-56.

66. O'Rourke, K.H.; Williamson, J.G. Globalization and History. The Evolution of a Nineteenth-Century Atlantic Economy, 1st ed.; MIT Press: Cambridge, MA, USA, 1999.

67. Centro de Propaganda Mercantil. Anuario Riera. Guía General de Cataluña; Centro de Propaganda Mercantil: Madrid, Spain, 1896.

68. Arauzo-Carod, J.M. Determinants of Industrial Location. An Application for Catalan Municipalities. Pap. Reg. Sci. 2005, 84, 105-120. [CrossRef]

69. Generalitat de Catalunya. Institut d'Estadística de Catalunya (Idescat). Altitude, Surface Area and Population. Municipalities. Available online: https:/ / www.idescat.cat/pub/?id=aec\&n=925\&lang=en (accessed on 15 February 2021 ).

70. Generalitat de Catalunya. Institut d'Estadística de Catalunya (Idescat). Geographical Indicators. Altitude and UTM Coordinates. Available online: http:/ / www.idescat.cat/pub/ ?id=inddt\&n=4700\&t=201300\&by=mun\&lang=en (accessed on 15 February 2021).

71. Giménez Guited, F. Guía Fabril e Industrial de España, 1st ed.; MIT Imprenta de Luís Tasso: Barcelona, Spain, 1862.

72. Ramon-Muñoz, R.; Ramon-Muñoz, J.M. The urban-rural height gap: Evidence from late nineteenth-century Catalonia. Doc. De Trab. De La Soc. Española De Hist. Agraria 2021, 2105.

73. Vidal Bendito, T. Exode rural i problemàtica demospacial a Catalunya (1860-1970). Est. Hist. Agric. 1979, 2, $193-2007$.

74. Nicolau, R. Els factors demogràfics del creixement econòmic: Catalunya 1787-1910. In Història Econòmica de la Catalunya Contemporània. Segle XIX. Població i Agricultura, 1st ed.; Nadal, J., Maluquer de Motes, J., Sudrià, C., Cabana, F., Eds.; Fundació Enciclopèdia Catalana: Barcelona, Spain, 1990; Volume 2, pp. 13-62. 
75. Camps, E. La Formación del Mercado de Trabajo Industrial en la Cataluña del Siglo XIX, 1st ed.; Ministerio de Trabajo y Seguridad Social: Madrid, Spain, 1995.

76. Nadal, J. El Fracaso de la Revolución Industrial en España, 1814-1913, 1st ed.; Ariel: Barcelona, Spain, 1975.

77. Nadal, J. La industria fabril española en 1900. Una aproximación. In La Economía Española en el Siglo XX. Una Perspectiva Histórica, 3rd ed.; Nadal, J., Carreras, A., Sudrià, C., Eds.; Ariel: Barcelona, Spain, 1989; pp. 23-61.

78. Generalitat de Catalunya. Institutd'Estadística de Catalunya (Idescat). Meteorology. Main observations. Counties. Available online: https: / / www.idescat.cat/pub/?id=aec\&n=214\&lang=en (accessed on 15 February 2021).

79. Hill, H.C. The Development of Chicago as a Center of the Meat Packing Industry. Miss. Vall. Hist. Rev. 1923, 10, 253-273. [CrossRef]

80. Yeager, M. Competition and Regulation: The Development of Oligopoly in the Meat Packing Industry, 1st ed.; Jai Press: London, UK, 1981.

81. Walsh, M. The Rise of the Midwestern Meat Packing Industry, 1st ed.; The Universtiy Press of Kentucky: Lexington, KY, USA, 1982.

82. Pacyga, D.A. Slaughterhouse: Chicago's Union Stock Yard and the World It Made, 1st ed.; The University Chicago Press: Chicago, IL, USA, 2015.

83. Thelle, M. The Meat City: Urban space and provision in industrial Copenhagen, 1880-1914. Urban Hist. 2018, 45, 233-252. [CrossRef]

84. Catalan, J.; Ramon-Muñoz, R. Marshall in Iberia. Industrial Districts and Leading Firms in the Creation of Competitive Advantage in Fashion Products. Enterp. Soc. 2013, 14, 327-359. [CrossRef]

85. Kompil, M.; Jacobs-Crisioni, C.; Dijkstra, L.; Lavalle, C. Mapping accessibility to generic services in Europe: A market-potential based approach. Sustain. Cities Soc. 2019, 47, 101372. [CrossRef]

86. Mora-García, R.T.; Céspedes-López, M.F.; Pérez-Sánchez, J.C.; Pérez-Sánchez, R. The kernel density estimation for the visualization of spatial patterns in urban studies. In Proceedings of the 15th International Multidisciplinary Scientific GeoConferences (SGEM2015), Albena, Bulgaria, 18-24 June 2015; Curran Associates, Inc.: New York, NY, USA, 2015; Volume 1, pp. 867-874.

87. Polzin, P.; Borges, J.; Coelho, A. An extended kernel density two-step floating catchment area method to analyze access to healthcare. Environ. Plan. B 2014, 41, 717-735. [CrossRef]

88. Grillitsch, M.; Rekers, J.; Sotarauta, M. Investigating agency: Methodological and empirical challenges. In Handbook on City and Regional Leadership, 1st ed.; Sotarauta, M., Beer, A., Eds.; Edward Elgar: Cheltenham, UK, 2021; pp. $302-323$.

89. Serra i Campdelacreu, J. Les Llonganisses de Vic, 1st ed.; (n.p.): Vic, Spain, 1869.

90. Salarich, J. El Salchichón de Vich; Círculo Literario, Ramon Anglada: Vic, Spain, 1870.

91. Cao Costoya, D. Les Elits i el Poder Local en una Societat en Transformació. Vic: Política, Cultura i Associacionisme. Unpublished Ph.D. Thesis, Universitat de Barcelona, Barcelona, Spain, 2014.

92. Molina-Morales, F.X. The Territorial Agglomerations of Firms: A Social Capital Perspective from the Spanish Tile Industry. Growth Chang. 2005, 36, 74-99. [CrossRef]

93. Mesquita, L.F. Starting over when the bickering never ends: Rebuilding aggregate trust among clustered firms through trust facilitators. Acad. Manag. Rev. 2007, 32, 72-91. [CrossRef]

94. Coletti, M. Technology and industrial clusters: How different are they to manage? Sci. Public Policy 2010, 37, 679-688. [CrossRef]

95. Gagné, M.; Townsend, S.H.; Bourgeois, I.; Hart, R.E. Technology cluster evaluation and growth factors: Literature review. Res. Eval. 2010, 19, 82-90. [CrossRef]

96. Ingstrup, M.B. The role of clusters facilitators. Int. J. Glob. Small Bus. 2010, 4, 25-40. [CrossRef]

97. Alberti, F.G.; Giusti, J.D.; Pizzurno, E. The role of institutions for collaboration in setting a competitive cluster ecosystem: The case of the French omega-3 cluster. Int. J. Compet. 2016, 1, 4-32. [CrossRef]

98. Sotarauta, M.; Beer, A.; Gibney, J. Making sense of leadership in urban and regional development. Reg. Stud. 2017, 51, 187-193. [CrossRef]

99. Junta Consultiva Agronómica. La ganadería en España: Avance sobre la riqueza pecuaria en 1891, formado por la Junta Consultiva Agronómica conforme a las memorias reglamentarias que en el citado año han redactado los ingenieros del Servicio Agronómico, Tomo I, 1st ed.; Dirección General de Agricultura, Industria y Comercio, L. Péant e Hijos: Madrid, Spain, 1892.

100. Pan-Montojo, J. La administración agraria en España, 1847-1907. Hist. Agr. 1995, 10, 67-88.

101. Dirección General de Contribuciones. Estadística Administrativa de la Contribución Industrial y del Comercio; Sobrinos de la Sucesora de M. Minuesa de los Ríos: Madrid, Spain, 1910.

102. Ministerio de Instrucción Pública y Bellas Artes. Censo de Población de España Según el Empadronamiento Hecho en la Península e Islas Baleares en 31 de Diciembre de 1910. Tomo Primero, 1st ed.; Imprenta de la Dirección General del Instituto Geográfico y Estadístico: Madrid, Spain, 1913.

103. Gosens, J.; Gilmanova, A.; Lilliestam, J. Windows of opportunity for catching up in formative clean-tech sectors and the rise of China in concentrated solar power. Environ. Innov. Soc. Transit. 2021, 39, 86-106. [CrossRef]

104. Morisson, A.; Mayer, H. An Agent of Change Against all Odds? The Case of Ledger in Vierzon, France. Local Econ. 2021, 36, 430-447. [CrossRef]

105. Iimi, A. Optimal Locational Choice for Agrobusinesses in Madagascar: An Application of Spatial Autoregressive Tobit Regression; World Bank Policy Research Working Paper 8488; World Bank: Washington, DC, USA, 2018. 